\title{
Review \\ The SCF Complex Is Essential to Maintain Genome and Chromosome Stability
}

\author{
Laura L. Thompson ${ }^{1,2}$, Kailee A. Rutherford ${ }^{1,2}$, Chloe C. Lepage ${ }^{1,2}$ and Kirk J. McManus ${ }^{1,2, * \text { D }}$ \\ 1 CancerCare Manitoba Research Institute, CancerCare Manitoba, Winnipeg, MB R3E 0V9, Canada; \\ Thompson.Laura1@mayo.edu (L.L.T.); rutherf6@myumanitoba.ca (K.A.R.); lepagec@myumanitoba.ca (C.C.L.) \\ 2 Department of Biochemistry \& Medical Genetics, University of Manitoba, Winnipeg, MB R3E 0J9, Canada \\ * Correspondence: Kirk.McManus@umanitoba.ca; Tel.: +1-204-787-2833
}

Citation: Thompson, L.L.;

Rutherford, K.A.; Lepage, C.C.; McManus, K.J. The SCF Complex Is Essential to Maintain Genome and Chromosome Stability. Int. J. Mol. Sci. 2021, 22, 8544. https://doi.org/ $10.3390 /$ ijms 22168544

Academic Editor: Antonella Zannetti

Received: 16 July 2021

Accepted: 5 August 2021

Published: 9 August 2021

Publisher's Note: MDPI stays neutral with regard to jurisdictional claims in published maps and institutional affiliations.

Copyright: (c) 2021 by the authors. Licensee MDPI, Basel, Switzerland. This article is an open access article distributed under the terms and conditions of the Creative Commons Attribution (CC BY) license (https:// creativecommons.org/licenses/by/ $4.0 /)$.

\begin{abstract}
The SKP1, CUL1, F-box protein (SCF) complex encompasses a group of 69 SCF E3 ubiquitin ligase complexes that primarily modify protein substrates with poly-ubiquitin chains to target them for proteasomal degradation. These SCF complexes are distinguishable by variable F-box proteins, which determine substrate specificity. Although the function(s) of each individual SCF complex remain largely unknown, those that have been characterized regulate a wide array of cellular processes, including gene transcription and the cell cycle. In this regard, the SCF complex regulates transcription factors that modulate cell signaling and ensures timely degradation of primary cell cycle regulators for accurate replication and segregation of genetic material. SCF complex members are aberrantly expressed in a myriad of cancer types, with altered expression or function of the invariable core SCF components expected to have a greater impact on cancer pathogenesis than that of the F-box proteins. Accordingly, this review describes the normal roles that various SCF complexes have in maintaining genome stability before discussing the impact that aberrant SCF complex expression and/or function have on cancer pathogenesis. Further characterization of the SCF complex functions is essential to identify and develop therapeutic approaches to exploit aberrant SCF complex expression and function.
\end{abstract}

Keywords: cancer; cell cycle; chromosome instability; chromosome stability; F-box protein; genome instability; SCF complex; therapeutic targeting; transcription; ubiquitin-proteasome system

\section{Introduction}

The SKP1, CUL1, F-box protein (SCF) complex is an E3 ubiquitin ligase that covalently attaches mono- or poly-ubiquitin chains onto protein targets. These distinctive protein modifications invoke a plethora of spatial and temporal outcomes, including altering protein localization, regulating protein activity, or targeting a protein for proteolytic degradation (reviewed in $[1,2]$ ). While each of these outcomes ultimately impact protein function, arguably the best studied relationship is that between protein poly-ubiquitination and the ubiquitin-proteosome system (UPS). In this regard, the SCF complex poly-ubiquitinates protein substrates targeting them for proteolytic degradation by the $26 \mathrm{~S}$ proteasome. Under normal conditions, the temporal degradation of specific proteins is critical to regulate many biological processes that are essential to maintain genome stability, including the regulation of various signal transduction cascades, cell cycle progression, DNA repair, and apoptosis. As a result, it is not difficult to envision how genomic alterations affecting the genes encoding the SCF complex will interfere with these key biological processes and promote genome instability to effectively contribute to cancer development and progression.

The focus of this review is to present evidence supporting the possibility that aberrant SCF complex expression underlies both tumor suppressor- and oncogene-like activities and has a potential impact on cancer development and progression. We first provide a brief background on the UPS and detail its central role in regulating protein abundance. We then describe the SCF complex, with a particular focus on the core and variable members that 
comprise the complex. We subsequently highlight several key biological processes that are regulated by the SCF complex and have strong pathogenic implications for cancer, including the regulation of transcription, downstream cancer-associated signaling pathways, and cell cycle, with our companion review article [3] focused on the DNA damage response, apoptosis, and centrosome biology. Finally, we end with a discussion of the most frequent types of genetic alterations involving the invariable core SCF complex members before presenting some future therapeutic strategies aimed at exploiting aberrant SCF complex expression and function, and the downstream impacts of aberrant protein turnover.

\section{Ubiquitin-Dependent Proteasomal Degradation}

The UPS is a major mechanism of targeted intracellular protein degradation that is essential for the spatial and temporal regulation of protein abundance (reviewed in [4]). The UPS consists of a large network of proteins and/or enzymes that collectively act to regulate the abundance of protein targets through two successive steps (Figure 1). First, a ubiquitin moiety is covalently attached to a lysine residue contained within a protein target and is subsequently modified through the repeated addition of ubiquitin moieties to ultimately produce a poly-ubiquitin chain. The poly-ubiquitinated protein is subsequently transported to the $26 \mathrm{~S}$ proteasome where it undergoes proteolytic degradation [4]. Briefly, the $26 \mathrm{~S}$ proteasome is a 2.5 megadalton macromolecular structure containing a cylindrical $20 \mathrm{~S}$ catalytic subunit harboring peptidase activity and a ring-shaped $19 \mathrm{~S}$ regulatory subunit consisting of structural components, ubiquitin receptors, and adenosine triphosphatases (ATPases) that bind, denature, and translocate protein targets into the $20 \mathrm{~S}$ proteolytic core [5].

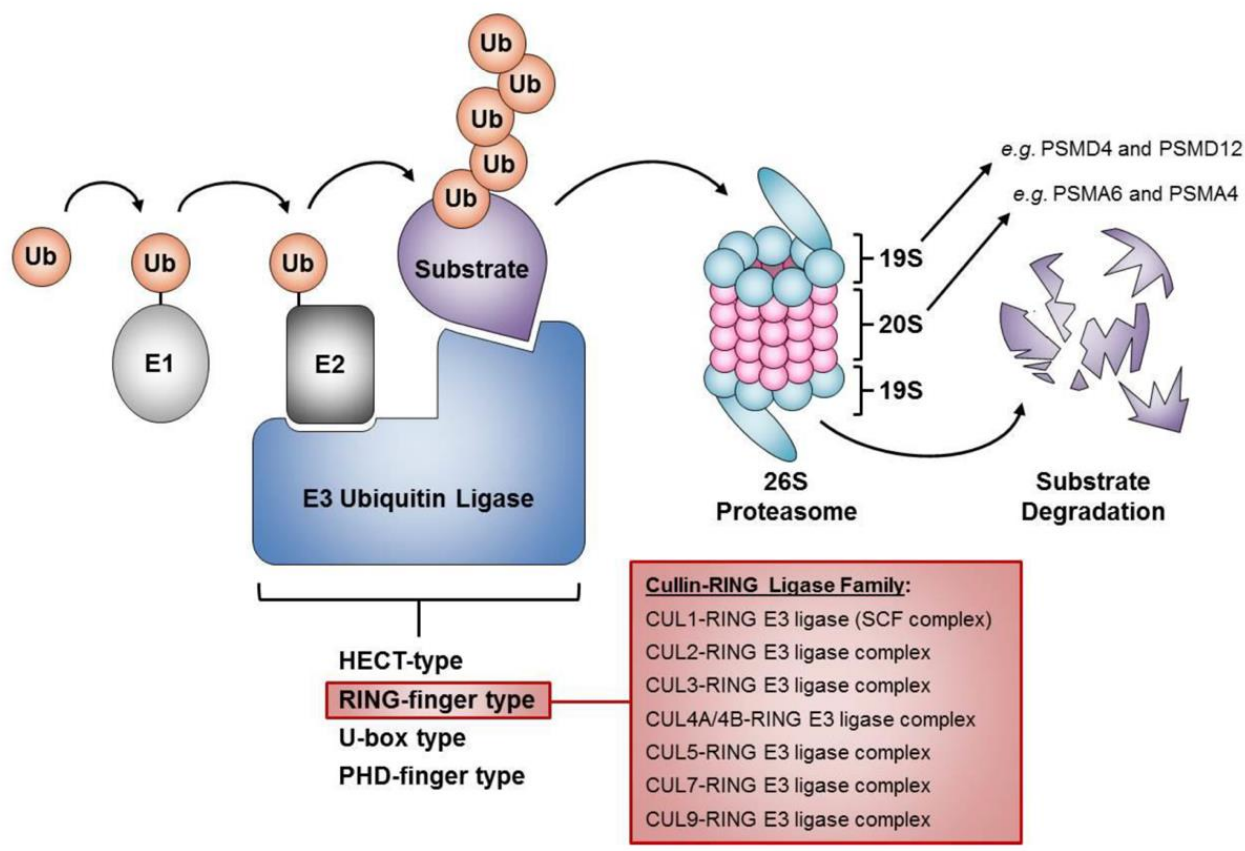

Figure 1. The Components of the ubiquitin-proteasome system. Substrates intended for degradation by the $26 \mathrm{~S}$ proteasome are poly-ubiquitinated through the concerted activities of an E1 ubiquitinactivating enzyme (E1), an E2 ubiquitin-conjugating enzyme (E2), and an E3 ubiquitin-protein ligase (E3). The four major E3 ubiquitin ligases families are listed and include the HECT, RING-finger, U-box, and PHD-finger families. Additionally, the seven RING-finger type Cullin-based ligases are listed (red box), which includes the prototypic CUL1-based SCF complex. Ub, Ubiquitin; PSMD4, Proteasome 26S Subunit Non-ATPase 4; PSMD12, Proteasome 26S Subunit Non-ATPase 12; PSMA6, Proteasome Subunit Alpha 6; and PSMA4, Proteasome Subunit Alpha 4.

Substrate poly-ubiquitination provides a high degree of specificity for the UPS and is performed by the sequential actions of three enzymes (Figure 1): (1) an E1 ubiquitin- 
activating enzyme; (2) an E2 ubiquitin-conjugating enzyme; and (3) an E3 ubiquitin ligase [6]. These three enzymes are responsible for the adenosine triphosphate (ATP)dependent ubiquitin activation by the E1, the conjugation of ubiquitin to the E2, and the transfer of ubiquitin to the protein target by the $\mathrm{E} 3$ to ultimately create a poly-ubiquitin chain linked through a series of lysine 48 (K48) to glycine 76 (G76) isopeptide bonds [6]. As it is the E3 enzyme that dictates substrate specificity for the UPS, a large number of E3 ubiquitin ligases ( 650) exist within the human genome (reviewed in [7]). The E3 ubiquitin ligases are divided into four main groups based on the E2-binding structural motif that they harbor, including the Homologous to the E6-AP Carboxyl Terminus (HECT), the U-box, the plant homeo domain (PHD)-finger, and the really interesting new gene (RING)-finger type (Figure 1). The RING-finger ligases are further classified into subfamilies, with the largest being the Cullin-based subfamily [8], of which the SCF complex is considered the prototypical Cullin-based, RING-finger type E3 enzyme.

\section{The SCF Complex}

The SCF complex is composed of three invariable core components, namely RING-box 1 (RBX1), a RING-finger protein that recruits the E2 ubiquitin-conjugating enzyme, cullin 1 (CUL1), the scaffolding protein, and the S-phase kinase-associated protein 1 (SKP1), an invariable adaptor component that bridges the core SCF complex with a variable Fbox protein and its corresponding protein target (Figure 2) [9]. Accordingly, the target specificity of the SCF complex is imparted by the F-box proteins, each of which recognizes and binds a distinct set of substrates. There are a total of 69 F-box proteins in humans, which are organized into three families according to their substrate recognition domains: (1) FBXW harboring WD40 repeats (e.g., FBXW7); (2) FBXL with leucine-rich repeats (e.g., FBXL1, better known as the S-phase kinase associated protein 2 [SKP2]); and (3) FBXO containing other domains (e.g., FBXO28) [8]. To regulate the abundance of specific protein targets, each F-box protein recruits one of its substrates (often phospho-activated) [10] to the core SCF complex to facilitate poly-ubiquitination and subsequent degradation by the $26 \mathrm{~S}$ proteasome (Figure 2) [11]. The presence of 69 different F-box genes implies that there are up to 69 unique SCF complexes, each of which regulates a myriad of protein targets [8]. Furthermore, SCF complex members, such as SKP1 and RBX1, have been shown to interact with non-prototypical binding partners to form additional E3 ubiquitin ligase complexes and regulate additional protein targets. For example, SKP1, RBX1, and FBXW8 can interact with CUL7 [12] to form an alternative Cullin-based RING-finger type E3 enzyme, which regulates a distinct subset of protein targets from those normally regulated by $\mathrm{SCF}^{\mathrm{FBXW}}$.

Unfortunately, the protein targets and functions for many of the F-box proteins and corresponding SCF complexes remain largely unknown in humans. However, the few well-characterized F-box proteins (e.g., SKP2, Cyclin F [CCNF], beta-transducin repeat containing E3 ubiquitin protein libase [ $\beta \operatorname{TrCP}]$ ) regulate substrates (e.g., cyclin E1 [13], cell division cycle 6 [CDC6] [14], and PLK4 [15]) involved in cellular processes that are essential for genome stability including cell cycle progression, centrosome duplication and dynamics, DNA replication and repair, and signal transduction and transcription. Thus, in-depth genetic and biochemical studies will be required to advance our rudimentary knowledge of each SCF complex and to reveal their specific protein targets and the biological processes they regulate. Gaining a greater understanding of each individual SCF complex component (e.g., SKP1, CUL1, RBX1, and the F-box proteins) is critical, as genetic alterations involving E3 subunits have detrimental impacts on the cell and are often implicated in disease pathophysiology (detailed in subsequent sections). For example, mutation, misexpression, or misregulation of the adaptor protein, SKP1, is expected to be especially damaging as it would prevent proper SCF complex formation, F-box protein recruitment, protein target poly-ubiquitination, and proteolytic degradation, which would adversely impact key biological pathways, culminating in cellular dysfunction and disease development. Indeed, SKP1 copy number losses are suggested to be pathogenic driver events in colorectal and high-grade serous ovarian cancers [16,17]. Thus, understanding the role each member 
of the SCF complex in diverse cellular contexts will be critical to gain novel insight into disease pathogenesis, and may hold diagnostic and/or prognostic implications that will be valuable in the clinical management of diseases such as cancer $[18,19]$.

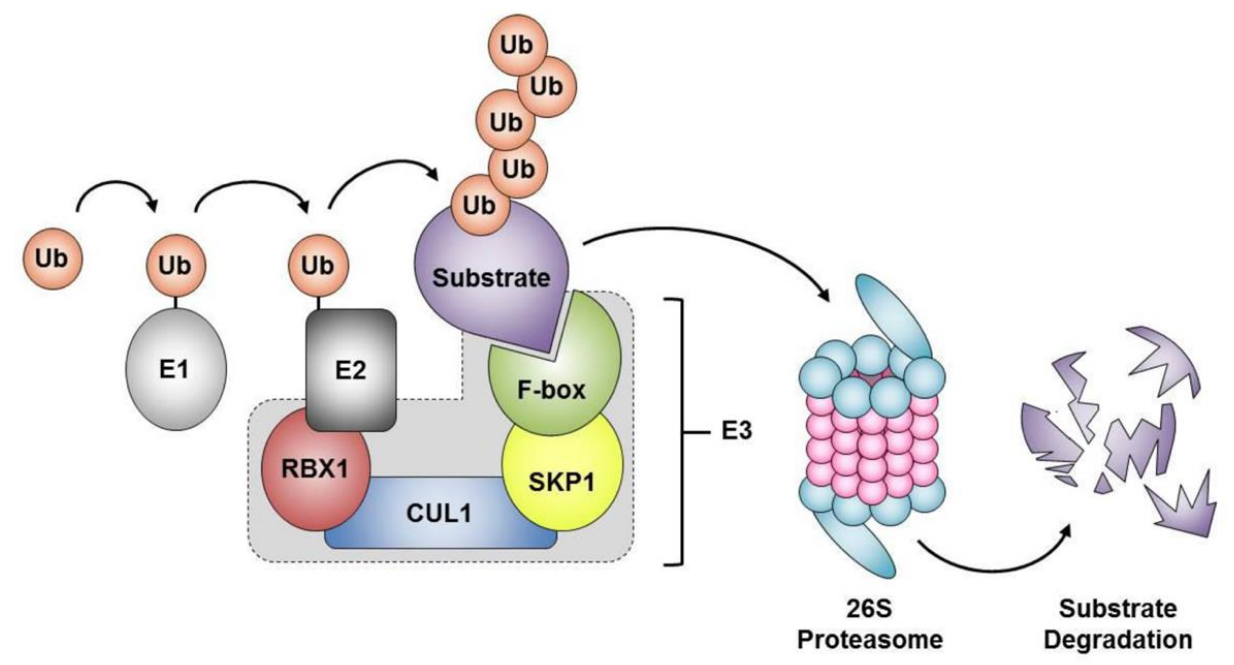

Figure 2. The SCF complex orchestrates proteolytic degradation by the $26 \mathrm{~S}$ proteasome. Schematic of the SCF complex consisting of four components, including invariant core members (SKP1, RBX1 and CUL1) and one of the 69 variable F-box proteins. The F-box proteins facilitate the transfer of ubiquitin from the E2-conjugating enzymes onto protein substrates, where poly-ubiquitination often denotes those targeted for proteolytic degradation via the $26 \mathrm{~S}$ proteasome. E1, E1 ubiquitin-activating enzyme; E2, E2 ubiquitin-conjugating enzyme; E3, E3 ubiquitin-protein ligase; Ub, Ubiquitin.

\section{The SCF Complex Regulates Transcription and Cancer-Associated Signaling Pathways}

The SCF complex plays an important role in gene transcription and regulates numerous cancer-related cell signalling pathways. In this regard, specific SCF complexes, such as $\mathrm{SCF}^{\beta \mathrm{TrCP}}$ and $\mathrm{SCF}^{\mathrm{FBXO} 28}$, mediate the levels and activities of many proto-oncogenic transcription factors including Snail [20], $\beta$-catenin [21], and MYC [22]. These transcription factors establish gene expression profiles that promote cancer-associated phenotypes including increased cellular proliferation, survival, and migration. When misregulated, these processes drive tumorigenesis and cancer metastasis through the epithelial to mesenchymal transition (EMT). For example, Snail is a transcriptional repressor of E-cadherin that is normally poly-ubiquitinated and targeted for degradation by SCF ${ }^{\beta T r C P}$ following phosphoactivation by glycogen synthase kinase 3 (GSK3). Direct Snail de-phosphorylation by small c-terminal domain phosphatase (SCP) inhibits its interaction with $\mathrm{SCF}^{\beta} \operatorname{TrCP}$, leading to increases in Snail levels [23]. Additionally, inhibition of GSK3 mediated by NFKB signalling prevents Snail phosphorylation, thereby preventing its degradation. NFKB signalling further supports Snail activity by inducing COP9 signalosome subunit 2 (COPS2)-mediated inhibition of $S F^{\beta \operatorname{TrCP}}$ [24]. In each case, the disruption of $\mathrm{SCF}^{\beta \operatorname{TrCP}}$-mediated Snail polyubiquitination and subsequent degradation leads to increased Snail levels that repress E-cadherin expression and drive EMT, cellular migration, and cancer metastasis [20,23,24]. Interestingly, however, the role of $\mathrm{SCF}^{\beta \operatorname{TrCP}}$ is both complex and contradictory, as it also regulates I $\kappa \mathrm{B} \alpha$ degradation, a negative regulator of the NFKB signalling pathway [21].

Another substrate of $\mathrm{SCF}^{\beta \operatorname{TrCP}}$ is $\beta$-catenin, a key component of the canonical WNT signalling pathway. Like Snail, $\beta$-catenin is also phospho-activated by GSK3 to enable $\mathrm{SCF}^{\beta \operatorname{TrCP}}$-mediated poly-ubiquitination and degradation [21]. Mutations interfering with $\beta$-catenin phosphorylation or with its binding to $\beta \operatorname{TrCP}$ result in $\beta$-catenin accumulation and constitutive canonical WNT pathway activation. WNT signaling inhibits GSK3, further increasing $\beta$-catenin levels and driving target gene transcription, cellular proliferation, invasion, de-differentiation, and tumor development. Accordingly, $\beta$-catenin overexpres- 
sion in human cancers, such as melanoma, correlate with disease progression [25]. As the SCF complex is responsible for regulation of oncogenic transcription factors, alterations involving core complex components (i.e., SKP1, CUL1, or RBX1) that disrupt SCF complex function can also contribute to the dysregulation of downstream substrates, such as $\beta$-catenin or Snail, and promote oncogenesis.

Interestingly, not all poly-ubiquitinated SCF substrates are targeted to the proteasome for degradation. Cepeda and colleagues [22] functionally characterized the F-box protein $\mathrm{FBXO} 28$, which acts as a transcriptional co-factor to positively regulate MYC target gene expression. FBXO28 is phosphorylated by CDK1 and cyclin-dependent kinases 1 (CDK1) and 2 (CDK2) in S and G2 phases of the cell cycle, which stabilizes FBXO28, promoting poly-ubiquitination of MYC by $\mathrm{SCF}^{\mathrm{FBXO} 28}$. However, rather than being targeted for degradation, poly-ubiquitinated MYC physically interacts with phosphorylated FBXO28 at the promoters of MYC target genes to recruit chromatin remodelling enzymes (e.g., histone acetyltransferase P300) and ultimately increase MYC-driven transcription. Hyper-activation of this pathway leads to overexpression of MYC target genes, increased proliferation, and neoplastic transformation $[22,26]$. Expectedly, FBXO28 is overexpressed in several tumor types, including breast, ovarian, testicular, and neuronal cancers, while immunohistochemical studies of tumor microarrays confirmed that phosphorylated FBXO28 was frequently overexpressed and associated with larger, more advanced tumors and poor survival in breast cancer patients [22]. Furthermore, the expression of an FBXO28 dominant negative mutant or silencing of wild-type $\mathrm{FBXO} 28$ hindered $\mathrm{SCF}^{\mathrm{FBXO} 28}$ ubiquitination of MYC and MYC-dependent transcription, transformation, and tumorigenesis [22]. It is interesting to note that additional SCF complexes, including $\mathrm{SCF}^{\mathrm{FBXW7}}$ [27] and $\mathrm{SCF}^{\mathrm{SKP} 2}$ [28], also bind and poly-ubiquitinate MYC to effectively mediate MYC expression and transcriptional activity, respectively. This inherent redundancy may be an important mechanism that allows for highly regulated, fine-tuned control of critical cancer-related proteins, such as MYC. These few examples highlight the complexity of various SCF complexes in the regulation of cancer-associated proteins and underscore the need for additional studies elucidating the critical roles that individual SCF complexes may have in transcription and downstream target regulation. Only once this has been completed will we obtain a more holistic understanding of the SCF complex and its potential role in disease pathogenesis and pathophysiology.

\section{SCF Complex Activity Is Essential to Mediate Cell Cycle Control and Prevent Tumorigenesis}

The mammalian cell cycle is a multi-faceted process that is strictly regulated for accurate replication and segregation of genetic material and cellular division to ultimately ensure appropriate development, function, and survival of an organism. In response to mitogenic or anti-proliferative signals, the cell cycle is predominately controlled through the action of CDKs, which are positively or negatively regulated by activating cyclins or CDK inhibitors (CKIs), respectively [29]. The complex interplay between these components regulates the phosphorylation-dependent activation of protein targets and translates the growth signals received by the cell into an appropriate response. To regulate progression through the various cell cycle stages, the abundance of cyclins and CKIs is tightly controlled and oscillates in a spatio-temporal manner. For example, nuclear cyclin E-CDK2 promotes DNA synthesis, while cyclin B-CDK1 initiates mitotic entry [30]. As such, the expression levels of each complex are high during the appropriate cell cycle phases and are rapidly degraded by the UPS upon completion of their stage-specific tasks to ensure unidirectionality and stepwise progression through the cell cycle. Thus, the SCF complex is critical for cell cycle progression as it controls the timely degradation of cyclins and CKIs. In fact, it is the SCF complex in conjunction with the anaphase-promoting complex/cyclosome $(\mathrm{APC} / \mathrm{C})$, a distinct $\mathrm{E} 3$ ubiquitin ligase that regulates anaphase initiation and mitotic exit, that coordinate cell cycle progression. 


\subsection{The SCF Complex Is Critical for the G1 to S-Phase Transition}

Although the SCF complex was initially believed to only regulate G1/S progression, it is now understood to have wide-ranging roles throughout the cell cycle and is active from late G1 to early M phase [30,31]. During G1, protein synthesis and cell growth are stimulated by SCF complex activity. For example, recruitment of pProgrammed cell death 4 (PDCD4) via the F-box protein $\beta \operatorname{TrCP}(\mathrm{FBXW1A})$, promotes $\mathrm{SCF}^{\beta{ }^{\beta r C P}}$-mediated poly-ubiquitination and proteasomal degradation of PDCD4. This prevents inhibition of the eukaryotic translation initiation factor (eIF4A) by PDCD4, enabling efficient protein translation and cell growth to occur [32]. In association with cyclin D1, CDK4 and CDK6 phosphorylate and inactivate the retinoblastoma protein family members pRB, p107 and p130, activating the E2F-related transcription factors [33]. In turn, E2F induces the expression of cyclins A, B, and, E during G1; however, these cyclin-CDK complexes are largely inhibited by CKIs (P21; P27; P57) to prevent premature DNA synthesis or initiation of mitosis at this stage [34-37]. APC/C further inhibits CDK1 and CDK2 activity by targeting the F-box protein SKP2, cyclins, and the CDK1-activating phosphatase cell division cycle 25A (CDC25A) [38]. In late G1, APC/C inhibition corresponds with increases in SKP2 expression, which achieves maximal abundance in S-phase and G2. SKP2 is now recruited to the SCF complex to promote CKI degradation, enhance CDK activity, and promote cell cycle progression. For example, $\mathrm{SCF}^{\mathrm{SKP} 2}$-mediated poly-ubiquitination and degradation of P27 activates the cyclin E-CDK2 kinase to initiate the G1/S transition [39,40]. Accordingly, reduced APC/C and CKI activity, increased cyclin and CDK levels, and activation of E2F transcription factor family members are all orchestrated by SCF complexes to mediate the transition from $\mathrm{G} 1$ to $S$ phase [30].

\subsection{The SCF Complex Functions within S-phase to Promote M-Phase Entry}

Once a cell enters S-phase, cyclin D1 is rapidly degraded through the poly-ubiquitination and proteolytic degradation enabled by $\mathrm{SCF}^{\mathrm{FBXO} 4}$ [41]. The activity of the S-phase complexes cyclin E-CDK2 and cyclin A-CDK2 promote DNA synthesis and S-phase progression [42]. Additionally, cyclin A-CDK2 maintains APC/C inhibition to ensure cyclin stability, while the E2F transcription factors induce early mitotic inhibitor 1 (EMI1), also known as FBXO5, expression to ensure continued APC/C inhibition throughout S-phase and G2 $[43,44]$. CDK1 activity is kept in check by the $\mathrm{SCF}^{\beta}{ }^{\mathrm{TrCP}}$-mediated degradation of CDC25A [45], and as the cell approaches G2, S-phase cyclin levels begin to decrease. Both non-phosphorylated cyclin E and phosphorylated cyclin E bound to CDK2 are targeted for degradation by $\mathrm{SCF}^{\mathrm{SKP} 2}$ and $\mathrm{SCF}^{\mathrm{FBXW7}}$ complexes, respectively [46,47]. Upon completion of S-phase, ribonucleotide reductase family member 2 (RRM2) is phosphorylated by $\mathrm{CDKs}$ leading to $\mathrm{SCF}$ CyclinF-mediated degradation, which prevents superfluous deoxyribonucleotide production [48].

Throughout G2, the cell prepares for M-phase transition, which is regulated predominantly by cyclin B-CDK1. Nuclear cyclin B levels are maintained low prior to G2/M by $\mathrm{SCF}^{\mathrm{NIPA}}$ (Non-imprinted in Prader-Willi/Angelman Syndrome) to prevent premature mitotic entry [49]. However, by late G2 SCF ${ }^{\beta} \operatorname{TrCP}$, no longer targets $C D C 25 \mathrm{~A}$, allowing CDC25A phosphatase to counteract the WEE1 G2 checkpoint kinase phosphorylationdependent inhibition of $C D K 1$. SCF ${ }^{\beta} \operatorname{TrCP}$ further promotes $C D K 1$ activation by targeting WEE1 for degradation at this stage [45], while cyclin B-CDK1 phosphorylates NIPA, preventing SCF ${ }^{N I P A}$ formation, resulting in cyclin $\mathrm{B}$ accumulation that ultimately drives mitotic entry [50].

\subsection{An Essential Role for the SCF Complex in Mitosis}

From prophase to metaphase, cyclin B-CDK1 regulates mitotic spindle assembly, nuclear envelope breakdown, and chromosome condensation. To promote mitotic progression, cyclin B-CDK1 indirectly upregulates APC/C. Briefly, cyclin B-CDK1 phosphorylates the

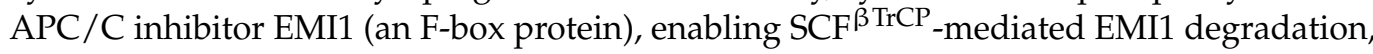
thereby increasing APC/C activity [45]. APC/C stimulates SKP2 degradation reducing 
SCF SKP2 activity, and increases the levels of CKIs such as P27 and P21 [36,40]. Additionally, APC /C targets mitotic cyclins A and B for degradation to dramatically reduce CDK1 activity [51]. CDK1 and 2 remain inactive until required for the next G1/S transition. Once the spindle assembly (mitotic) checkpoint is satisfied following bipolar attachment of paired sister chromatids that exhibit tension, the APC/C promotes securin degradation to initiate chromosome segregation (reviewed in [30,52]). Although APC/C is primarily responsible for anaphase onset, the SCF complex also contributes to this process as $\mathrm{SCF}^{\beta \operatorname{TrCP}}$ targets the mitotic spindle assembly protein, BORA (Aurora Kinase A Activator) for degradation, allowing progression through anaphase and mitotic spindle disassembly [53]. Finally, the APC/C mediates chromosome decompaction, cytokinesis, nuclear envelope formation and subsequently re-establishes the G1 environment [30,54], when the entire cell cycle regulatory process can begin again.

\subsection{Aberrant SCF Complex Expression and Function Adversely Impacts Cell Cycle Progression}

The examples presented in the preceding sections illustrate how SCF complex-mediated degradation of positive and negative cell cycle regulators is essential to maintain both genome stability and cell cycle control. Mutation, misexpression, and/or misregulation of the individual SCF complex components are therefore predicted to induce cellular dysfunction, unchecked proliferation, and genome instability [55]. In fact, many of the genes encoding the F-box proteins presented above are frequently altered in cancer. For example, the $\beta \operatorname{TrCP}$ gene $(B T R C)$ is somatically altered in various cancer types [56-58] and the aberrant protein exhibits both oncogenic and tumor suppressive activities within cells. $\beta \operatorname{TrCP}$ is frequently overexpressed in colorectal [59], pancreatic [60], and hepatoblastoma tumors [61], whereas loss-of-function alterations occur in gastric cancers [62]. Additionally, SKP2 (SCF $\left.{ }^{S K P 2}\right)$, the F-box protein required for S-phase entry, is overexpressed in numerous cancers including breast [63], Kaposi's sarcoma [64], T-cell lymphoma [65], and melanoma [66], with increasing SKP2 expression correlating with diminished P27 (CKI) expression, advanced cancer progression, and poor patient prognosis [63-66]. Interestingly, siRNA-based silencing of SKP2 in melanoma cells causes increases in P27 abundance and growth suppression, both in in vitro and in vivo mouse models [67], while SKP2 knockout mice exhibit increases in cyclin E and P27 expression levels, polyploidy, supernumerary centrosomes, proliferation defects, and increases in apoptosis [13]. Collectively, these data suggest that, under normal conditions, $\beta \operatorname{TrCP}$ and SKP2 expression and function are tightly regulated to maintain accurate cell cycle progression, ensure genome stability, and prevent cancer development.

Certain F-box proteins predominately exhibit tumor-suppressive functions in cell cycle control. For example, FBXO4 is frequently under-expressed or somatically mutated in specific tumor types (e.g., esophageal carcinomas), which impairs $\mathrm{SCF}^{\mathrm{FBXO} 4}$ activity and contributes to cyclin D1 overexpression. Cyclin D1-dependent transcription of cyclins (detailed above) drives cell cycle progression and oncogenic transformation [41,68], as established by FBXO4 knockout mice that develop lymphomas and dendritic cell sarcomas, along with mammary, uterine, and hepatocellular carcinomas [69]. Similarly, the F-box tumor suppressor FBXW7 [70], exhibits loss of function alterations in $\sim 6 \%$ of cancers [56-58] with inactivation preventing $\mathrm{SCF}^{\mathrm{FBXW7}}$-dependent proteolytic degradation of cyclin $\mathrm{E}$, which corresponds with increases in aneuploidy, nuclear aberrations, micronucleus formation, multi-polar spindles, as well as chromosome congression, cohesion, and segregation defects [71,72]. Cyclin F (FBXO1) is yet another F-box protein suspected to be a tumor suppressor as it is under-expressed in $\sim 60 \%$ of hepatocellular carcinomas and reduced expression correlates with increased tumor sizes and numbers, advanced grade, stage and poor patient outcomes [73]. Conversely, F-box proteins can also harbor opposing oncogene-like activities. For example, EMI1 is a predicted oncoprotein that is frequently overexpressed in many cancers including lymphoma, ovarian, and hepatocellular carcinoma [74]. Conceptually, increased EMI1 expression prevents APC-mediated degradation of SKP2 and the mitotic cyclins, which will promote cell cycle progression $[43,51,74]$. In ovarian and hepatocellular carcinoma, EMI1 overexpression induces increases in cellular 
proliferation and tetraploidization, and is predictive of advanced tumor grade and poor prognosis [74]. Evidently, the SCF complexes regulating cell cycle progression can harbor tumor suppressor and/or oncogenic activities if not properly regulated in a spatio-temporal manner, which can lead to neoplastic transformation.

\section{The Core SCF Complex Members Are Frequently Altered in Cancer}

While genetic alterations or misregulation of the individual F-box proteins are associated with genomic instability and cancer pathogenesis, less is known about the tumorigenic roles of the invariable SCF components SKP1, CUL1, and RBX1. Conceptually, disruption of core SCF complex members is expected to produce complex outcomes involving the misregulation of a large number of protein targets, and may induce more severe or extensive aberrant phenotypes than those attributed to the misregulation of individual F-box proteins. To investigate this hypothesis, genetic and biochemical studies are required to fully realize the implications that SKP1, CUL1, and RBX1 dysfunction have for cell cycle misregulation, cellular dysfunction, genome instability, and tumorigenesis. Indeed, several genetic studies performed in malignant [17] and non-malignant [16] human contexts have established that reduced SKP1, CUL1, and RBX1 expression induces chromosome instability (CIN), a prevalent form of genome instability. Briefly, CIN is defined as an increase in the rate at which whole chromosomes or large chromosome fragments are gained or lost, and is an established driver of both genetic and cellular heterogeneity (reviewed in $[19,75]$ ). Importantly, CIN is an enabling hallmark of cancer [55], associated with early disease events including cellular transformation [76,77] and intra-tumoral heterogeneity [78-80]) and late disease events such as metastasis [81-84], drug resistance [85,86], and poor patient survival (reviewed in [19]).

Patient-based data from The Cancer Genome Atlas (TCGA) provides further evidence supporting the possibility that aberrant expression and/or function of the core SCF complex components (SKP1, CUL1, and RBX1) have pathogenic roles in cancer [58]. Genetic analyses performed in cBioPortal (https:/ /www.cbioportal.org, accessed on 2-12 May 2021) [56,57] reveal that the three members are somatically altered in 12 common cancer types (Figure $3 \mathrm{~A}$ ), and that non-synonymous mutations are rare, typically occurring in $\leq 1 \%$ of cancers for $S K P 1$ and $R B X 1$ or $\leq 5 \%$ for CUL1 [58]. It should be noted however, that the CUL1 coding sequence (NM_003592.3; 2331 base pairs [bp]; 776 amino acids [aa]) is 4.7and 7.1-times larger than SKP1 (NM_170679; 492 bp; 163 aa) and RBX1 (NM_014248.4; 327 bp; 108 aa), respectively, and therefore the increased frequency of mutations may simply reflect its larger size. Nonetheless, the mutational loads are predominantly distributed across the entire coding sequence of each gene, supporting potential tumor suppressor functions (Figure 3B), rather than focally restricted to specific regions or hotspots typical of an oncogene $[87,88]$.

Beyond somatic mutations, SKP1, CUL1, and RBX1 gene copy number alterations including deep deletions (loss of 2 alleles), shallow deletions (loss of 1 allele), gains (gain of 1 allele), and amplifications (gain of $\geq 2$ alleles) are frequently observed in all 12 cancer types (Figure 3C). In all instances, deep deletions and gene amplifications are extremely rare, generally occurring in $<1 \%$ of all cancers, except for CUL1 amplifications that occur in $\sim 7 \%$ of ovarian cancer cases (Figure 3C). Furthermore, copy number losses occur most commonly for SKP1 and RBX1, whereas copy number gains are most prevalent for CUL1 [56-58]. These findings suggest that gene expression thresholds may exist whereby complete loss of expression may be lethal to a cell (i.e., essential genes), while extreme increases in expression may disrupt stoichiometries of core components to severely impact normal cell function/homeostasis and induce lethality. Collectively, SKP1 copy number losses (shallow and deep deletions) range from $7 \%$ to $44 \%$ in prostate and ovarian cancers, respectively, while CUL1 and RBX1 losses range from $2 \%$ (glioblastoma) to $23 \%$ (head and neck) and $10 \%$ (prostate) to $80 \%$ (ovarian), respectively. Conversely, copy number gains (gains plus amplifications) for SKP1, CUL1, and RBX1 range from 3\% (uterine) to 31\% (liver), $12 \%$ (cervical) to $80 \%$ (glioblastoma), and $1 \%$ (prostate) to $22 \%$ (head and neck), respectively. 


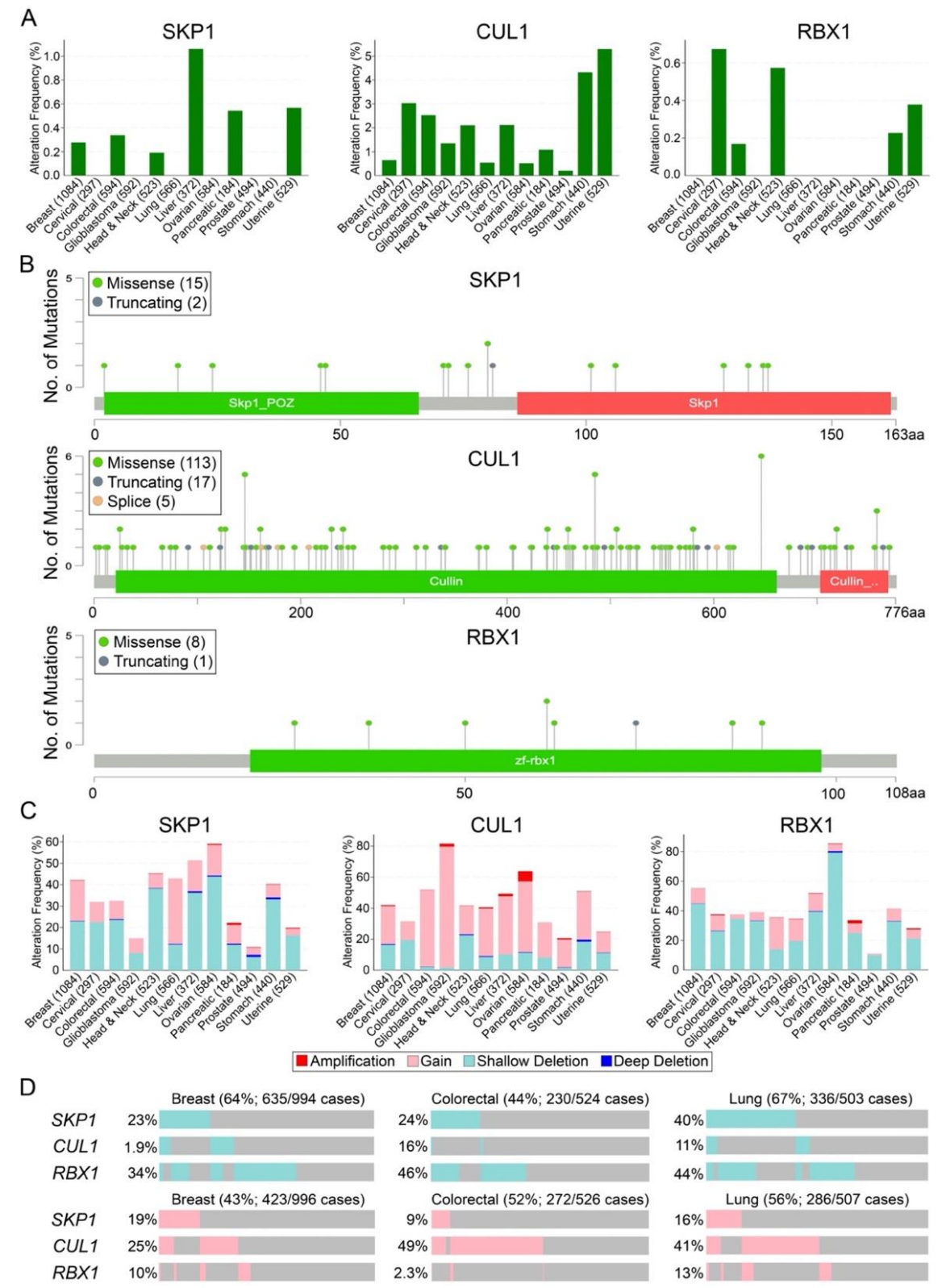

Figure 3. Mutation frequencies of the three core SCF complex members in 12 common cancer types. (A) The frequency of total SKP1 (left), CUL1 (middle) and RBX1 (right) mutations, including missense, truncating, inframe, and fusions in 12 common cancer types (total cases) assessed using TCGA pancancer atlas data [58]. Note that missense and truncating mutations were identified for all three genes, while CUL1 also harbors splice mutations. (B) Schematics from cBioPortal [56,57] mapping the protein positions of the corresponding mutations in SKP1 (top), CUL1 (middle), and RBX1 (bottom). Note that, in general, the distribution of the encoded mutations is spread across the entirety of each protein in agreement with a tumor suppressor mutational load. (C) Prevalence of SKP1 (left), CUL1 (middle), and RBX1 (right) copy number alterations including deep deletions, shallow deletions, gains, and amplifications in 12 common cancer types (total cases) [56-58]. Note that, in general, SKP1 and RBX1 exhibit more frequent copy number losses, whereas CUL1 generally exhibits more gains. (D) Oncoprint data for breast, colorectal, and lung cancers depicting the individual and cumulative frequencies of SKP1,CUL1, and RBX1 shallow deletions (top) or copy number gains (bottom) [58]. Vertical alignments within either the shallow deletions or gains categories identify samples from the same patient; patient-specific comparisons cannot be made between categories. 
Interestingly, when shallow deletions or gains of SKP1, CUL1, and RBX1 are assessed concurrently within three commonly diagnosed cancers, there is a compounding effect (Figure 3D). More specifically, the combined frequencies of SKP1, CUL1, and RBX1 shallow deletions are $64 \%$ (breast), $44 \%$ (colorectal) and $67 \%$ (lung), while the combined frequencies of SKP1, CUL1, and RBX1 gains are 43\% (breast), 52\% (colorectal), and 56\% (lung). Thus, while there are instances of individual patient tumors harboring simultaneous copy number alterations for more than one core SCF complex component (Figure 3D), this compounding effect suggests that many patients harbour only a single gene copy number alteration (i.e., mutual exclusivity). Considering that SKP1, CUL1, and RBX1 are core components contained within all SCF complexes, copy number alterations affecting these three genes have the potential to severely impair SCF complex expression and function, resulting in the misregulation of many substrates and cellular pathways. Intuitively, the proportion of cancers with aberrant SCF complex expression will increase when copy number alterations for the 69 F-box proteins are also considered. Collectively, these findings agree with the possibility that aberrant SCF complex expression and function may be a significant, yet underappreciated driver of many common cancer types. Importantly, while the copy number alterations detailed above suggest SKP1, CUL1, and RBX1 may harbor tumor suppressor- and/or oncogene-like properties, these outwardly contrasting activities have also been described for many well-established cancer-associated genes including BTRC [56-58], TP53 [89-91], RAD54B [92], and USP22 [93].

The above data suggest that copy number alterations for SKP1, CUL1, and/or RBX1 adversely impact normal SCF complex function, resulting in the misregulation of many biological processes to ultimately drive cancer pathogenesis. Importantly, a central assumption behind this hypothesis is that the gene copy number alterations correspond with changes in expression at the level of the protein. Indeed, mRNA expression analyses of TGCA data [56-58] reveal robust and pervasive positive correlations between gene copy number alterations and gene expression levels. For example, in breast, colorectal, and lung cancers, increased copy numbers for SKP1, CUL1, and RBX1 correspond with significant increases in mean expression values and ranges (Figure 4). The potential for both tumor suppressor-like and oncogene-like activities is further bolstered through analyses of additional gene expression datasets. In agreement with the predominant copy number alterations detailed above, mRNA expression analyses performed using the In Silico Transcriptomics (IST) database (https:/ /ist.medisapiens.com, accessed on 2-12 May 2021) [94] reveal considerable variation in SKP1 (ENSG00000113558) and CUL1 (ENSG00000055130) mRNA expression in normal and tumor tissues (Figure 5A); unfortunately, no RBX1 expression data are available. In agreement with the most prevalent copy number alterations detailed above, SKP1 mRNA expression levels are often reduced within tumor samples relative to normal tissues, whereas CUL1 expression is frequently increased. However, these relationships are not universal as some cancers do exhibit increases in SKP1 expression relative to control tissues (e.g., chronic lymphocytic leukemia, head and neck, and liver). Likewise, several cancers, including chronic myelogenous leukemia and testicular cancer, exhibit decreases in CUL1 expression. Moreover, supplementary mRNA expression data from the Oncomine database (https: / / www.oncomine.org, accessed on 2-12 May 2021) [95] corroborate that SKP1,CUL1, and RBX1 can be significantly under or overexpressed within a variety of cancer types relative to control tissues (Figure $5 B$ ). Collectively, these findings support the possibility that SKP1, CUL1, and RBX1 encode tumor suppressor- or oncogene-like activities depending on whether they are under- or over-expressed. In both cases, the altered expression of SCF complex components is expected to adversely impact SCF complex function and disrupt critical pathways required for genome stability, gene transcription, signal transduction and cell cycle progression, leading to cancer development and progression. 

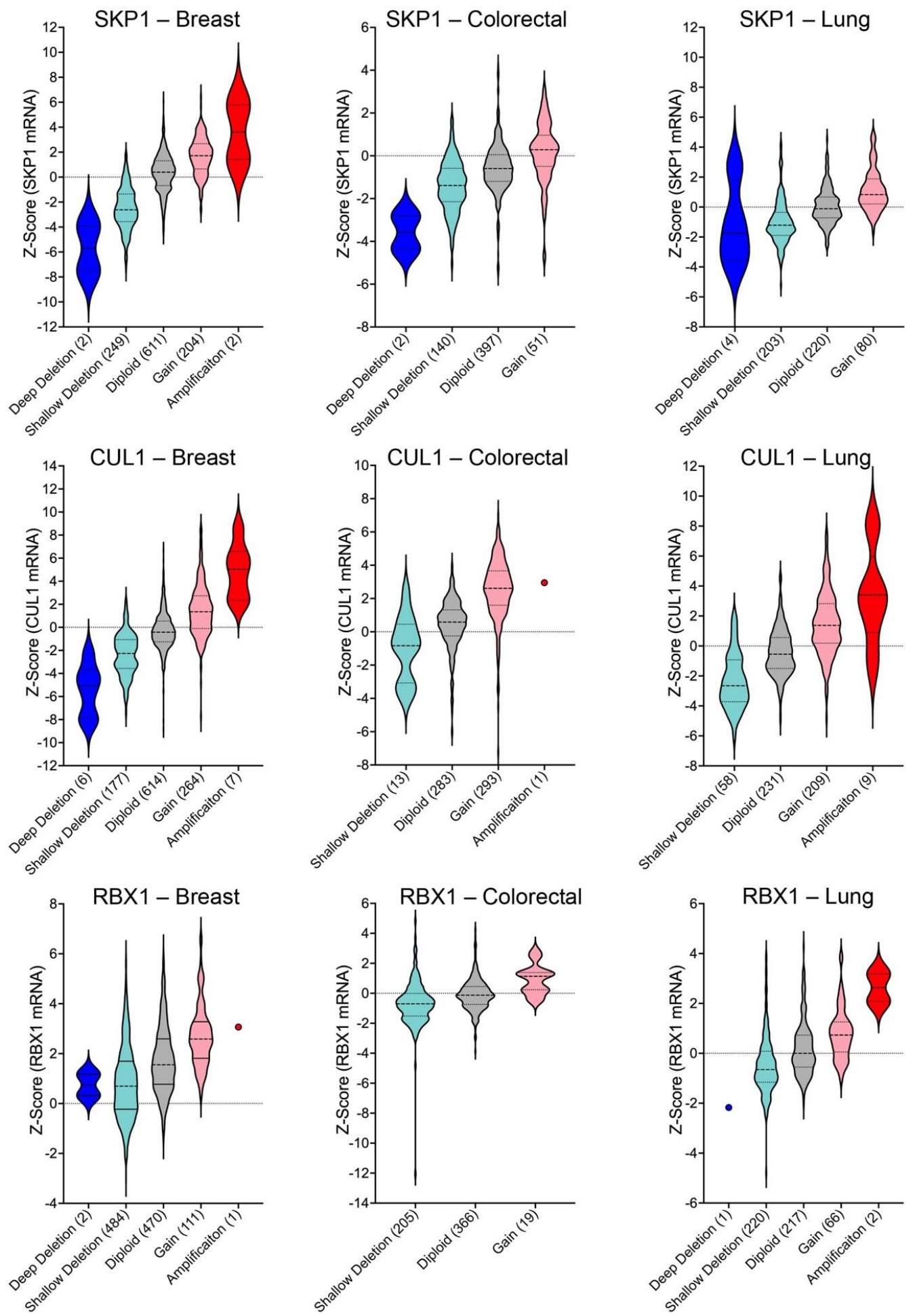

Figure 4. Gene copy number changes correspond with SKP1, CUL1, and RBX1 expression levels. (A) Violin plots of TCGA pan-cancer data [58] from the three most commonly diagnosed cancers (i.e., breast, colorectal and lung). SKP1 (top), CUL1 (middle), and RBX1 (bottom) copy number alterations (deep deletions; shallow deletions; gains; amplifications) and diploid cases are presented along the $\mathrm{x}$-axis with total case numbers indicated within brackets. Note that categories with only single cases are identified by circles and that in general, deep deletions, and amplifications are rare. 
A

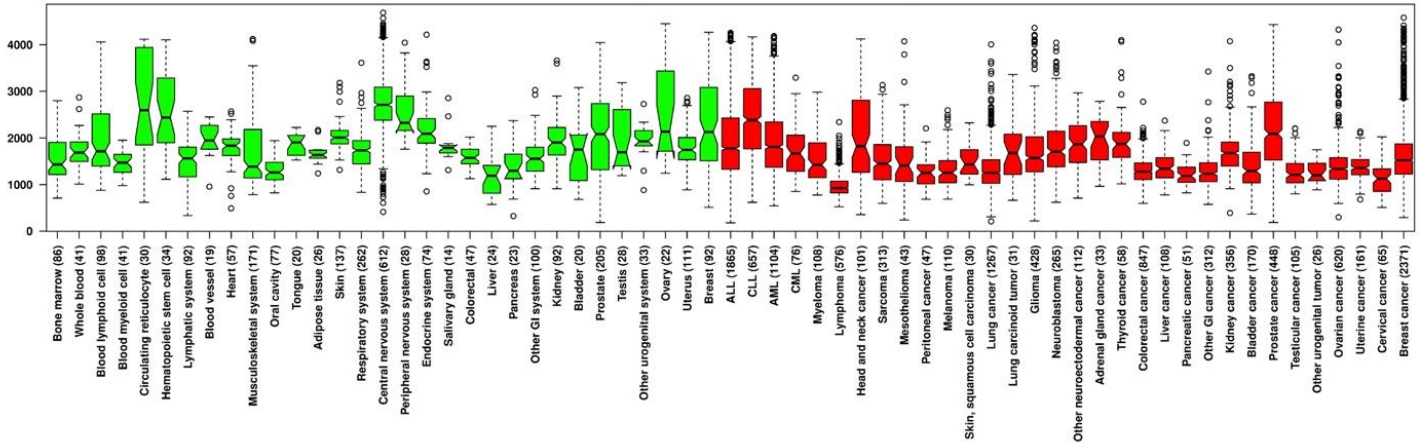

CUL1 (ENSG00000055130)

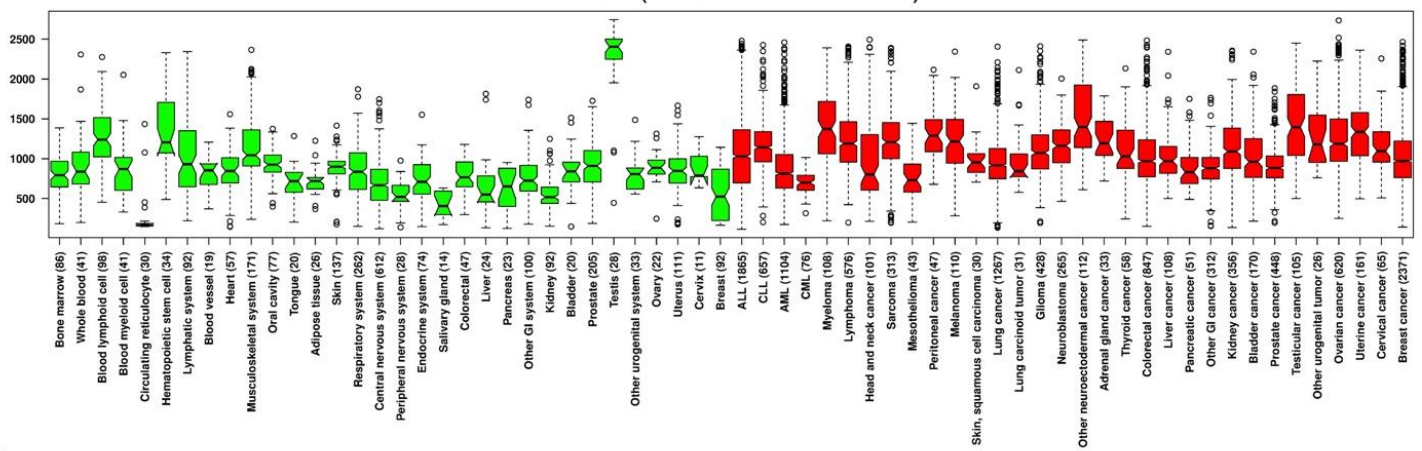

B
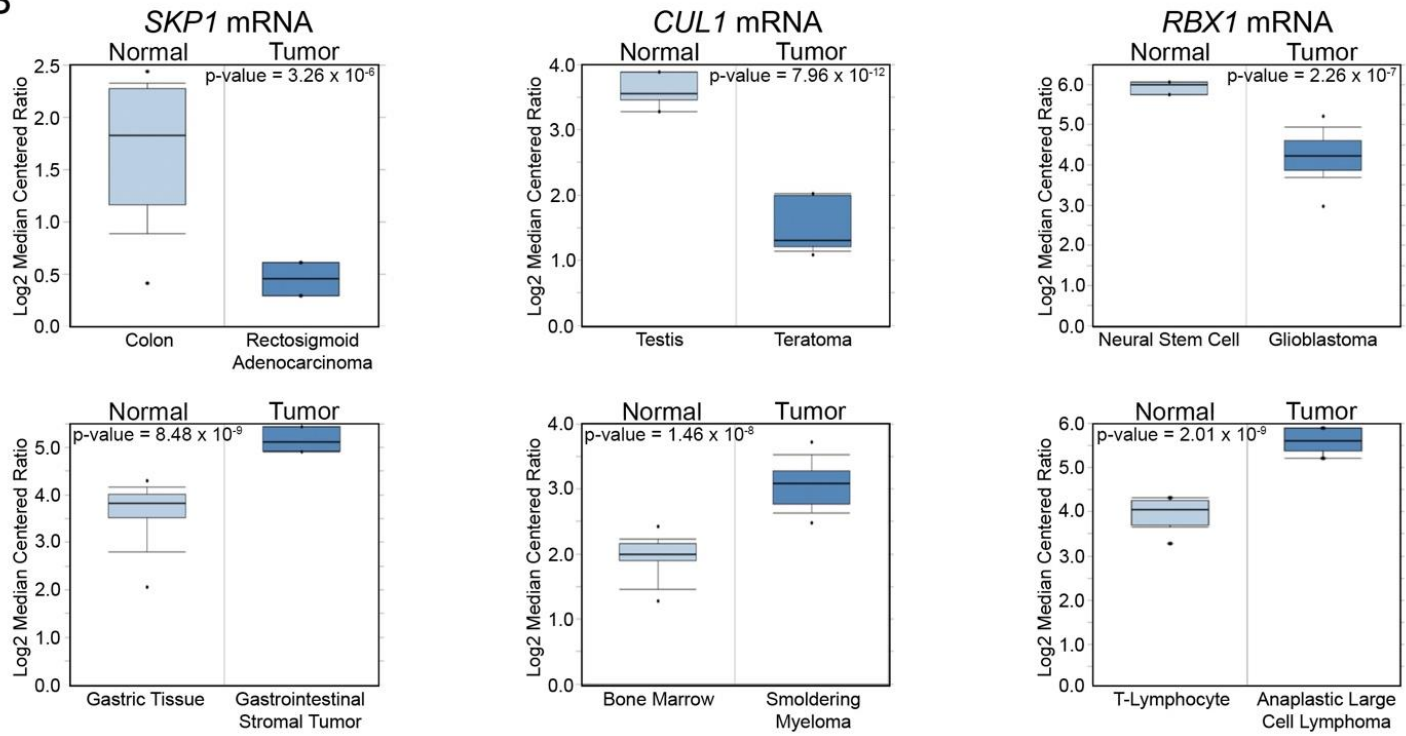

Figure 5. SKP1 and CUL1 exhibit altered expression in numerous cancer types. (A) Box-and-whisker plots displaying SKP1 (top) and CUL1 (bottom) mRNA expression levels in healthy (green) and cancer (red) tissues (total cases); RBX1 expression data are not available. Boxes denote the interquartile range (25th, 50th, and 75th percentiles), while the whiskers extend 1.5-times the interquartile range and open circles identifying outliers. The notches in the boxes allow for visual comparisons between conditions; if two notches are non-overlapping, this is a strong indicator that the medians are different. Data and graph obtained using the in silico transcriptomics (IST) database [94]. In general, SKP1 mRNA expression levels are frequently reduced in cancers relative to the corresponding normal tissues, whereas CUL1 levels are predominantly increased. (B) Box plots displaying SKP1, CUL1, and RBX1 mRNA expression levels for normal and tumor tissues. Boxes display the interquartile range with black dots identifying minimum/maximum values. Note that the top graphs display instances where significant decreases in mRNA expression occur within the tumors relative to normal tissue, while the bottom graphs provide examples where significant increases in expression occur. Graphs and statistical analyses were generated using the Oncomine database [95]. 


\section{Targeting the SCF Complex for Cancer Treatments}

Targeting the SCF complex, or more specifically the three invariable components (SKP1, CUL1, and RBX1), may appear counterintuitive due to the extensive array of protein targets and the multitude of biological pathways that the SCF complex regulates and the potential for adverse side effects. However, broad-spectrum approaches employing proteasome inhibitors, such as Bortezomib [96] or indirect SCF inhibitors, for example, MLN4924 (NEDD8-activating enzyme inhibitor that prevents CUL1 neddylation and indirectly inactivates CUL1) [97], have proven effective in the treatment of leukemia, lymphoma, and myeloma, lending support for the use of SCF complex inhibitors [98]. Additionally, preclinical and clinical evidence indicates that cancer cells harboring an aberrant UPS exhibit enhanced sensitivity to proteasome or SCF complex-targeting inhibitors relative to normal cells, thus enabling the administration of lower doses that still provide effective treatment with reduced overall side effects [99]. Based on these findings, therapeutic strategies exploiting aberrant SKP1, CUL1, or RBX1 expression and/or function represent promising avenues worthy of pursuit. Three distinct therapeutic strategies are presented below including synthetic genetic approaches, low-dose SCF inhibitors to exacerbate copy number loses of SCF complex members, and proteolysis-targeting chimeric molecules (PROTACS).

Concerted research efforts have recently focused on designing precision medicine approaches to therapeutically exploit the genetic aberrations driving cancer development and progression. In this regard, synthetic genetic approaches can be designed to target cancer cells harboring either copy number losses or gains. For example, the SKP1, CUL1, and RBX1 copy number losses can be therapeutically exploited using synthetic lethal paradigms, analogous to how ovarian and breast cancers with reduced BRCA1/2 expression are treated using poly [ADP-ribose] polymerase (PARP) inhibitors, such as olaparib or niraparib [100]. Briefly, synthetic lethality refers to a rare and lethal combination of two independently viable mutations (reviewed in [101]). Conceptually, a synthetic lethal strategy seeks to exploit the genetic defects contained within cancer cells (e.g., SKP1, CUL1, or RBX1 loss) to induce lethality, while leaving the normal surrounding cells and tissues unaffected. Thus, the copy number losses and hypomorphic expression (loss-of-function) typically associated with tumor suppressor genes can be therapeutically exploited by downregulating or inhibiting a synthetic lethal interactor (drug target). Indeed, Burdova and colleagues [102] employed this strategy to uncover a synthetic lethal interaction between cyclin F (F-box protein) an CHEK1 inhibition, while Brough [103] et al. identified components of the SCF complex (e.g., SKP1 and SKP2) as synthetic lethal interactors of RB1 in triple negative breast cancer contexts. Similarly, copy number gains and hypermorphic expression (gain-of-function) associated with oncogenes could also be therapeutically exploited through a strategy referred to as synthetic dosage lethality (reviewed in [101]). First established in budding yeast [104], synthetic dosage lethal approaches are gaining in popularity due to the inherent challenges in developing drugs that target oncogenes without enzymatic activities, including transcription factors such as c-MYC. Thus, similar strategies could be employed to identify synthetic dosage lethal interactors (drug targets) for cells harboring copy number gains in SKP1, CUL1, or RBX1. As with synthetic lethal approaches, this systemic strategy would preferentially restrict killing to only those cancer cells that harbour increased expression of SCF complex components. In either case, synthetic genetic screening strategies using siRNA, shRNA, CRISPR/Cas9 techniques could be employed to identify candidate drug targets (synthetic lethal or synthetic dosage lethal interactors) capable of exploiting either copy number losses or gains. These approaches could consist of both direct tests, including candidate interactors identified through cross-species approaches, or unbiased approaches such as genome-wide screens (see [101]). Moreover, chemogenetic screens employing individual compounds or compound libraries could be extremely beneficial in identifying small molecule inhibitors that induce preferential killing of cancer cells with copy number losses or gains in SKP1, CUL1, or RBX1, which will have tremendous clinical utility across a myriad of cancer types. Alternatively, personalized strategies employing synergistic drug combinations targeting independent drug sensitivities may also have therapeutic 
potential [105]. Thus, it is conceivable that small molecule inhibitors targeting two or more independent synthetic lethal interactors of the SCF complex (i.e., those encoding functions within distinct biological pathways) may prove especially effective in combating cancers with copy number losses in SCF complex member genes. In any case, these synthetic lethal interactors, alone or in combination, will have to be evaluated for their clinical utility and pan-specificity across a myriad of cancer types and patient samples.

As an alternative strategy, low-dose SCF complex (SKP1, CUL1, or RBX1) inhibitors may prove beneficial in cancers already harboring shallow deletions (single allele loss). If, as predicted, all three genes are essential, then further diminishing or inhibiting their residual expression and/or function below a specific threshold is expected to induce lethality. Still, this hypothetical systemic approach is not without risk as each gene was recently identified as a CIN gene $[16,17,106]$ and CIN is an enabling hallmark associated with early (e.g., cellular transformation [76,77] and intra-tumoral heterogeneity [78-80]) and late (e.g., metastasis [81-83] and drug resistance [85,86]) etiological events. Thus, such a systemic approach is expected to induce side effects within the normal surrounding cells or tissues; however, if reduced expression or inhibition can be selectively delivered to the cancer cells, then a large therapeutic window is expected to open. Nevertheless, rigorous genetic, biochemical and pharmacologic pre-clinical and clinical studies will be essential to discern whether this strategy will become a viable treatment option.

A final emerging therapeutic approach that may prove effective in cancers with SKP1, CUL1, or RBX1 alterations is PROTACS (reviewed in [107-110]). Briefly, PROTACS are chimeric proteins that link a protein target to an F-box protein for SCF-mediated proteolytic degradation [109]. Conceivably, PROTACS could enable conditional or tissue-specific destruction of overexpressed proteins by enabling the targeted destruction of cancer cells harboring: (1) hypermorphic expression of SKP1, CUL1, or RBX1 due to copy number gains in those specific genes; or (2) the downstream proteins (i.e., oncogenes such as cyclin E1 [16,17]), normally targeted by the SCF complex for proteolytic degradation, but exhibit increased abundance due to SKP1, CUL1, or RBX1 copy number losses. Although theoretical, several teams have already developed PROTACS targeting key oncogenes and 'undruggable' pathway genes (e.g., Myc [111,112]) found many different cancers (e.g., multiple myeloma, mantle cell lymphoma, and Burkitt's lymphoma [113-115]). Accordingly, it may be feasible to create the chimeric molecules to target either of the contexts described above.

In summary, the therapeutic strategies detailed above mandate a deeper understanding of the aberrant genetics and biology that promote carcinogenesis to enable effective precision medicine approaches. Nevertheless, and before these strategies can come to fruition, additional studies are required to better characterize SKP1, CUL1, and RBX1, the associated 69 distinct SCF complexes with respect to the biological pathways that they regulate, and their individual impacts on cancer development and progression. Additionally, a myriad of future studies are required to identify candidate drug targets, test small molecule inhibitors, and optimize lead compounds before preclinical and ultimately clinical trials assessing drug safety and efficacy can be pursued. Thus, the translation of aberrant SCF complex biology into the clinic represents a critical new area of research that may offer tremendous promise for the development of novel and highly effective precision medicine strategies aimed at improving the lives and outcomes of those living with cancer.

Author Contributions: Conceptualization L.L.T., K.A.R., C.C.L. and K.J.M.; formal analyses, L.L.T. and K.J.M.; writing—original draft preparation L.L.T., K.A.R., C.C.L. and K.J.M.; writing-review and editing, L.L.T., K.A.R., C.C.L. and K.J.M.; supervision, K.J.M.; funding acquisition, K.J.M. All authors have read and agreed to the published version of the manuscript.

Funding: Operational support is provided by a Natural Sciences and Engineering Research Council of Canada (NSERC) Alexander Graham Bell Canadian Graduate Scholarship (L.L.T.), a Canadian Institutes of Health Research Canada Graduate (MSc) Scholarship (K.A.R.), a Research Manitoba/CancerCare Manitoba Studentship (K.A.R.), a Canadian Institutes of Health Research Canada 
Graduate Scholarship (C.C.L.), an NSERC Discovery Grant (K.J.M.; RGPIN: 2018-05007) and a CancerCare Manitoba Foundation Operating Grant (K.J.M.).

Institutional Review Board Statement: Ethical review and approval were waived for this study, due to the use of publicly available datasets from TCGA Research Network (https:/ / www.cancer.gov / tcga) [58], IST (https:/ /ist.medisapiens.com) [94] and Oncomine (https://www.oncomine.org) [95] and accessed online from 2-12 May 2021. No other human specimens or clinical data were utilized.

Informed Consent Statement: All patient data presented in Figures 3 and 4 are from TCGA pancancer atlas datasets [58] made publicly available through cBioPortal (https:/ / cbioportal.org, 2-12 May 2021) [56,57] and for which informed consent was previously obtained. Similarly, data presented in Figure 5A were extracted from the publicly available IST database (https: / /ist.medisapiens.com, 2-12 May 2021) [94], while those in Figure 5B are from the openly accessible Oncomine database (https:/ / www.oncomine.org, 2-12 May 2021) [95].

Data Availability Statement: Patient-related data from Figures 3, 4 and 5A,B are based on data available from TCGA Research Network (https: / www.cancer.gov/tcga) [58], IST [94] and Oncomine [95], respectively, and accessed online from 2-12 May 2021.

Acknowledgments: We acknowledge that the CancerCare Manitoba Research Institute is located on original lands of Anishinaabeg, Cree, Oji-Cree, Dakota and Dene peoples, and on the homeland of the Métis Nation. We respect the Treaties that were made on these territories and acknowledge the harms and mistakes of the past. We dedicate ourselves to move forward in partnership with Indigenous communities in a spirit of reconciliation and collaboration. We thank members of the McManus laboratory for constructive criticisms during the writing of this review. We also acknowledge the ongoing support of the CancerCare Manitoba Research Institute and the CancerCare Manitoba Foundation.

Conflicts of Interest: The authors declare no conflict of interest. The funders had no role in the design of the study; in the collection, analyses, or interpretation of data; in the writing of the manuscript, or in the decision to publish the results.

\section{References}

1. Hershko, A.; Ciechanover, A. The ubiquitin system. Annu. Rev. Biochem. 1998, 67, 425-479. [CrossRef]

2. Swatek, K.N.; Komander, D. Ubiquitin modifications. Cell Res. 2016, 26, 399-422. [CrossRef]

3. Thompson, L.L.; Rutherford, K.A.; Lepage, C.C.; McManus, K.J. Aberrant SKP1 Expression: Diverse Mechanisms Impacting Genome and Chromosome Stability. Int. J. Mol. Sci. 2021. under review.

4. Kleiger, G.; Mayor, T. Perilous journey: A tour of the ubiquitin-proteasome system. Trends Cell Biol. 2014, 24, 352-359. [CrossRef]

5. Pack, C.G.; Yukii, H.; Toh-e, A.; Kudo, T.; Tsuchiya, H.; Kaiho, A.; Sakata, E.; Murata, S.; Yokosawa, H.; Sako, Y.; et al. Quantitative live-cell imaging reveals spatio-temporal dynamics and cytoplasmic assembly of the $26 \mathrm{~S}$ proteasome. Nat. Commun. 2014, 5, 3396. [CrossRef]

6. Thrower, J.S.; Hoffman, L.; Rechsteiner, M.; Pickart, C.M. Recognition of the polyubiquitin proteolytic signal. EMBO J. 2000, 19, 94-102. [CrossRef] [PubMed]

7. Deshaies, R.J.; Joazeiro, C.A. RING domain E3 ubiquitin ligases. Annu. Rev. Biochem. 2009, 78, 399-434. [CrossRef] [PubMed]

8. Jin, J.; Cardozo, T.; Lovering, R.C.; Elledge, S.J.; Pagano, M.; Harper, J.W. Systematic analysis and nomenclature of mammalian F-box proteins. Genes Dev. 2004, 18, 2573-2580. [CrossRef] [PubMed]

9. Chandra Dantu, S.; Nathubhai Kachariya, N.; Kumar, A. Molecular dynamics simulations elucidate the mode of protein recognition by Skp1 and the F-box domain in the SCF complex. Proteins 2016, 84, 159-171. [CrossRef] [PubMed]

10. Yoshida, Y.; Murakami, A.; Tanaka, K. Skp1 stabilizes the conformation of F-box proteins. Biochem. Biophys. Res. Commun. 2011, 410, 24-28. [CrossRef]

11. Kulathu, Y.; Komander, D. Atypical ubiquitylation-The unexplored world of polyubiquitin beyond Lys48 and Lys63 linkages. Nat. Rev. Mol. Cell Biol. 2012, 13, 508-523. [CrossRef]

12. Dias, D.C.; Dolios, G.; Wang, R.; Pan, Z.Q. CUL7: A DOC domain-containing cullin selectively binds Skp1.Fbx29 to form an SCF-like complex. Proc. Natl. Acad. Sci. USA 2002, 99, 16601-16606. [CrossRef]

13. Nakayama, K.; Nagahama, H.; Minamishima, Y.A.; Matsumoto, M.; Nakamichi, I.; Kitagawa, K.; Shirane, M.; Tsunematsu, R.; Tsukiyama, T.; Ishida, N.; et al. Targeted disruption of Skp2 results in accumulation of cyclin E and p27(Kip1), polyploidy and centrosome overduplication. EMBO J. 2000, 19, 2069-2081. [CrossRef]

14. Walter, D.; Hoffmann, S.; Komseli, E.S.; Rappsilber, J.; Gorgoulis, V.; Sorensen, C.S. SCF(Cyclin F)-dependent degradation of CDC6 suppresses DNA re-replication. Nat. Commun. 2016, 7, 10530. [CrossRef] 
15. Cunha-Ferreira, I.; Bento, I.; Pimenta-Marques, A.; Jana, S.C.; Lince-Faria, M.; Duarte, P.; Borrego-Pinto, J.; Gilberto, S.; Amado, T.; Brito, D.; et al. Regulation of autophosphorylation controls PLK4 self-destruction and centriole number. Curr. Biol. CB 2013, 23, 2245-2254. [CrossRef] [PubMed]

16. Lepage, C.C.; Palmer, M.C.L.; Farrell, A.C.; Neudorf, N.M.; Lichtensztejn, Z.; Nachtigal, M.W.; McManus, K.J. Reduced SKP1 and CUL1 expression underlies increases in Cyclin E1 and chromosome instability in cellular precursors of high-grade serous ovarian cancer. Br. J. Cancer 2021, 124, 1699-1710. [CrossRef] [PubMed]

17. Thompson, L.L.; Baergen, A.K.; Lichtensztejn, Z.; McManus, K.J. Reduced SKP1 Expression Induces Chromosome Instability through Aberrant Cyclin E1 Protein Turnover. Cancers 2020, 12, 531. [CrossRef] [PubMed]

18. Thompson, L.L.; Jeusset, L.M.; Lepage, C.C.; McManus, K.J. Evolving Therapeutic Strategies to Exploit Chromosome Instability in Cancer. Cancers 2017, 9, 151. [CrossRef]

19. Vishwakarma, R.; McManus, K.J. Chromosome Instability; Implications in Cancer Development, Progression, and Clinical Outcomes. Cancers 2020, 12, 824. [CrossRef]

20. Becker, K.F.; Rosivatz, E.; Blechschmidt, K.; Kremmer, E.; Sarbia, M.; Hofler, H. Analysis of the E-cadherin repressor Snail in primary human cancers. Cells Tissues Organs 2007, 185, 204-212. [CrossRef]

21. Winston, J.T.; Strack, P.; Beer-Romero, P.; Chu, C.Y.; Elledge, S.J.; Harper, J.W. The SCFbeta-TRCP-ubiquitin ligase complex associates specifically with phosphorylated destruction motifs in IkappaBalpha and beta-catenin and stimulates IkappaBalpha ubiquitination in vitro. Genes Dev. 1999, 13, 270-283. [CrossRef]

22. Cepeda, D.; Ng, H.F.; Sharifi, H.R.; Mahmoudi, S.; Cerrato, V.S.; Fredlund, E.; Magnusson, K.; Nilsson, H.; Malyukova, A.; Rantala, J.; et al. CDK-mediated activation of the SCF(FBXO) (28) ubiquitin ligase promotes MYC-driven transcription and tumourigenesis and predicts poor survival in breast cancer. EMBO Mol. Med. 2013, 5, 999-1018. [CrossRef] [PubMed]

23. Wu, Y.; Evers, B.M.; Zhou, B.P. Small C-terminal domain phosphatase enhances snail activity through dephosphorylation. J. Biol. Chem. 2009, 284, 640-648. [CrossRef]

24. Huang, C. Roles of E3 ubiquitin ligases in cell adhesion and migration. Cell Adhes. Migr. 2010, 4, 10-18. [CrossRef] [PubMed]

25. Sinnberg, T.; Menzel, M.; Ewerth, D.; Sauer, B.; Schwarz, M.; Schaller, M.; Garbe, C.; Schittek, B. beta-Catenin signaling increases during melanoma progression and promotes tumor cell survival and chemoresistance. PLoS ONE 2011, 6, e23429. [CrossRef]

26. Dang, C.V. c-Myc target genes involved in cell growth, apoptosis, and metabolism. Mol. Cell. Biol. 1999, 19, 1-11. [CrossRef]

27. Sato, M.; Rodriguez-Barrueco, R.; Yu, J.; Do, C.; Silva, J.M.; Gautier, J. MYC is a critical target of FBXW7. Oncotarget 2015, 6, 3292-3305. [CrossRef] [PubMed]

28. Zhang, Q.; Spears, E.; Boone, D.N.; Li, Z.; Gregory, M.A.; Hann, S.R. Domain-specific c-Myc ubiquitylation controls c-Myc transcriptional and apoptotic activity. Proc. Natl. Acad. Sci. USA 2013, 110, 978-983. [CrossRef] [PubMed]

29. Bai, C.; Sen, P.; Hofmann, K.; Ma, L.; Goebl, M.; Harper, J.W.; Elledge, S.J. SKP1 connects cell cycle regulators to the ubiquitin proteolysis machinery through a novel motif, the F-box. Cell 1996, 86, 263-274. [CrossRef]

30. Bassermann, F.; Eichner, R.; Pagano, M. The ubiquitin proteasome system-Implications for cell cycle control and the targeted treatment of cancer. Biochim. Biophys. Acta 2014, 1843, 150-162. [CrossRef]

31. Nakayama, K.I.; Nakayama, K. Regulation of the cell cycle by SCF-type ubiquitin ligases. Semin. Cell Dev. Biol. 2005, 16, 323-333. [CrossRef] [PubMed]

32. Dorrello, N.V.; Peschiaroli, A.; Guardavaccaro, D.; Colburn, N.H.; Sherman, N.E.; Pagano, M. S6K1- and betaTRCP-mediated degradation of PDCD4 promotes protein translation and cell growth. Science 2006, 314, 467-471. [CrossRef]

33. Halaban, R. Melanoma cell autonomous growth: The Rb/E2F pathway. Cancer Metastasis Rev. 1999, 18, 333-343. [CrossRef] [PubMed]

34. Geng, Y.; Eaton, E.N.; Picon, M.; Roberts, J.M.; Lundberg, A.S.; Gifford, A.; Sardet, C.; Weinberg, R.A. Regulation of cyclin E transcription by E2Fs and retinoblastoma protein. Oncogene 1996, 12, 1173-1180.

35. Schulze, A.; Zerfass, K.; Spitkovsky, D.; Middendorp, S.; Berges, J.; Helin, K.; Jansen-Durr, P.; Henglein, B. Cell cycle regulation of the cyclin A gene promoter is mediated by a variant E2F site. Proc. Natl. Acad. Sci. USA 1995, 92, 11264-11268. [CrossRef]

36. Bornstein, G.; Bloom, J.; Sitry-Shevah, D.; Nakayama, K.; Pagano, M.; Hershko, A. Role of the SCFSkp2 ubiquitin ligase in the degradation of p21Cip1 in S phase. J. Biol. Chem. 2003, 278, 25752-25757. [CrossRef]

37. Kamura, T.; Hara, T.; Kotoshiba, S.; Yada, M.; Ishida, N.; Imaki, H.; Hatakeyama, S.; Nakayama, K.; Nakayama, K.I. Degradation of p57Kip2 mediated by SCFSkp2-dependent ubiquitylation. Proc. Natl. Acad. Sci. USA 2003, 100, 10231-10236. [CrossRef]

38. Donzelli, M.; Squatrito, M.; Ganoth, D.; Hershko, A.; Pagano, M.; Draetta, G.F. Dual mode of degradation of Cdc25 A phosphatase. EMBO J. 2002, 21, 4875-4884. [CrossRef] [PubMed]

39. Carrano, A.C.; Eytan, E.; Hershko, A.; Pagano, M. SKP2 is required for ubiquitin-mediated degradation of the CDK inhibitor p27. Nat. Cell Biol. 1999, 1, 193-199. [CrossRef]

40. Tsvetkov, L.M.; Yeh, K.H.; Lee, S.J.; Sun, H.; Zhang, H. p27(Kip1) ubiquitination and degradation is regulated by the SCF(Skp2) complex through phosphorylated Thr187 in p27. Curr. Biol. CB 1999, 9, 661-664. [CrossRef]

41. Barbash, O.; Lee, E.K.; Diehl, J.A. Phosphorylation-dependent regulation of SCF(Fbx4) dimerization and activity involves a novel component, 14-3-3varepsilon. Oncogene 2011, 30, 1995-2002. [CrossRef] [PubMed]

42. Zhang, H.; Kobayashi, R.; Galaktionov, K.; Beach, D. p19Skp1 and p45Skp2 are essential elements of the cyclin A-CDK2 S phase kinase. Cell 1995, 82, 915-925. [CrossRef] 
43. Reimann, J.D.; Gardner, B.E.; Margottin-Goguet, F.; Jackson, P.K. Emi1 regulates the anaphase-promoting complex by a different mechanism than Mad2 proteins. Genes Dev. 2001, 15, 3278-3285. [CrossRef]

44. Hsu, J.Y.; Reimann, J.D.; Sorensen, C.S.; Lukas, J.; Jackson, P.K. E2F-dependent accumulation of hEmi1 regulates $S$ phase entry by inhibiting APC(Cdh1). Nat. Cell Biol. 2002, 4, 358-366. [CrossRef] [PubMed]

45. Watanabe, N.; Arai, H.; Nishihara, Y.; Taniguchi, M.; Watanabe, N.; Hunter, T.; Osada, H. M-phase kinases induce phosphodependent ubiquitination of somatic Wee1 by SCFbeta-TrCP. Proc. Natl. Acad. Sci. USA 2004, 101, 4419-4424. [CrossRef]

46. Clurman, B.E.; Sheaff, R.J.; Thress, K.; Groudine, M.; Roberts, J.M. Turnover of cyclin E by the ubiquitin-proteasome pathway is regulated by cdk2 binding and cyclin phosphorylation. Genes Dev. 1996, 10, 1979-1990. [CrossRef]

47. Koepp, D.M.; Schaefer, L.K.; Ye, X.; Keyomarsi, K.; Chu, C.; Harper, J.W.; Elledge, S.J. Phosphorylation-dependent ubiquitination of cyclin E by the SCFFbw7 ubiquitin ligase. Science 2001, 294, 173-177. [CrossRef]

48. D' Angiolella, V.; Donato, V.; Forrester, F.M.; Jeong, Y.T.; Pellacani, C.; Kudo, Y.; Saraf, A.; Florens, L.; Washburn, M.P.; Pagano, M. Cyclin F-mediated degradation of ribonucleotide reductase M2 controls genome integrity and DNA repair. Cell 2012, 149, 1023-1034. [CrossRef]

49. Klitzing, C.; Huss, R.; Illert, A.L.; Froschl, A.; Wotzel, S.; Peschel, C.; Bassermann, F.; Duyster, J. APC/C(Cdh1)-mediated degradation of the F-box protein NIPA is regulated by its association with Skp1. PLoS ONE 2011, 6, e28998. [CrossRef]

50. Bassermann, F.; von Klitzing, C.; Munch, S.; Bai, R.Y.; Kawaguchi, H.; Morris, S.W.; Peschel, C.; Duyster, J. NIPA defines an SCF-type mammalian E3 ligase that regulates mitotic entry. Cell 2005, 122, 45-57. [CrossRef] [PubMed]

51. Reimann, J.D.; Freed, E.; Hsu, J.Y.; Kramer, E.R.; Peters, J.M.; Jackson, P.K. Emi1 is a mitotic regulator that interacts with Cdc20 and inhibits the anaphase promoting complex. Cell 2001, 105, 645-655. [CrossRef]

52. Chang, L.; Barford, D. Insights into the anaphase-promoting complex: A molecular machine that regulates mitosis. Curr. Opin. Struct. Biol. 2014, 29, 1-9. [CrossRef]

53. Seki, A.; Coppinger, J.A.; Du, H.; Jang, C.Y.; Yates, J.R., III; Fang, G. Plk1- and beta-TrCP-dependent degradation of Bora controls mitotic progression. J. Cell Biol. 2008, 181, 65-78. [CrossRef]

54. Acquaviva, C.; Pines, J. The anaphase-promoting complex/cyclosome: APC/C. J. Cell Sci. 2006, 119, 2401-2404. [CrossRef]

55. Hanahan, D.; Weinberg, R.A. Hallmarks of cancer: The next generation. Cell 2011, 144, 646-674. [CrossRef]

56. Cerami, E.; Gao, J.; Dogrusoz, U.; Gross, B.E.; Sumer, S.O.; Aksoy, B.A.; Jacobsen, A.; Byrne, C.J.; Heuer, M.L.; Larsson, E.; et al. The cBio cancer genomics portal: An open platform for exploring multidimensional cancer genomics data. Cancer Discov. 2012, 2, 401-404. [CrossRef]

57. Gao, J.; Aksoy, B.A.; Dogrusoz, U.; Dresdner, G.; Gross, B.; Sumer, S.O.; Sun, Y.; Jacobsen, A.; Sinha, R.; Larsson, E.; et al. Integrative analysis of complex cancer genomics and clinical profiles using the cBioPortal. Sci. Signal. 2013, 6, pl1. [CrossRef] [PubMed]

58. Hoadley, K.A.; Yau, C.; Hinoue, T.; Wolf, D.M.; Lazar, A.J.; Drill, E.; Shen, R.; Taylor, A.M.; Cherniack, A.D.; Thorsson, V.; et al. Cell-of-Origin Patterns Dominate the Molecular Classification of 10,000 Tumors from 33 Types of Cancer. Cell 2018, 173, 291-304 e296. [CrossRef] [PubMed]

59. Ougolkov, A.; Zhang, B.; Yamashita, K.; Bilim, V.; Mai, M.; Fuchs, S.Y.; Minamoto, T. Associations among beta-TrCP, an E3 ubiquitin ligase receptor, beta-catenin, and NF-kappaB in colorectal cancer. J. Natl. Cancer Inst. 2004, 96, 1161-1170. [CrossRef] [PubMed]

60. Muerkoster, S.; Arlt, A.; Sipos, B.; Witt, M.; Grossmann, M.; Kloppel, G.; Kalthoff, H.; Folsch, U.R.; Schafer, H. Increased expression of the E3-ubiquitin ligase receptor subunit betaTRCP1 relates to constitutive nuclear factor-kappaB activation and chemoresistance in pancreatic carcinoma cells. Cancer Res. 2005, 65, 1316-1324. [CrossRef] [PubMed]

61. Koch, A.; Waha, A.; Hartmann, W.; Hrychyk, A.; Schuller, U.; Waha, A.; Wharton, K.A., Jr.; Fuchs, S.Y.; von Schweinitz, D.; Pietsch, T. Elevated expression of Wnt antagonists is a common event in hepatoblastomas. Clin. Cancer Res. Off. J. Am. Assoc. Cancer Res. 2005, 11, 4295-4304. [CrossRef]

62. Kim, C.J.; Song, J.H.; Cho, Y.G.; Kim, Y.S.; Kim, S.Y.; Nam, S.W.; Yoo, N.J.; Lee, J.Y.; Park, W.S. Somatic mutations of the beta-TrCP gene in gastric cancer. APMIS Acta Pathol. Microbiol. Immunol. Scand. 2007, 115, 127-133. [CrossRef]

63. Chan, C.H.; Li, C.F.; Yang, W.L.; Gao, Y.; Lee, S.W.; Feng, Z.; Huang, H.Y.; Tsai, K.K.; Flores, L.G.; Shao, Y.; et al. The Skp2-SCF E3 ligase regulates Akt ubiquitination, glycolysis, herceptin sensitivity, and tumorigenesis. Cell 2012, 149, 1098-1111. [CrossRef] [PubMed]

64. Penin, R.M.; Fernandez-Figueras, M.T.; Puig, L.; Rex, J.; Ferrandiz, C.; Ariza, A. Over-expression of p45(SKP2) in Kaposi's sarcoma correlates with higher tumor stage and extracutaneous involvement but is not directly related to p27(KIP1) down-regulation. Mod. Pathol. 2002, 15, 1227-1235. [CrossRef]

65. Latres, E.; Chiarle, R.; Schulman, B.A.; Pavletich, N.P.; Pellicer, A.; Inghirami, G.; Pagano, M. Role of the F-box protein Skp2 in lymphomagenesis. Proc. Natl. Acad. Sci. USA 2001, 98, 2515-2520. [CrossRef] [PubMed]

66. Li, Q.; Murphy, M.; Ross, J.; Sheehan, C.; Carlson, J.A. Skp2 and p27kip1 expression in melanocytic nevi and melanoma: An inverse relationship. J. Cutan. Pathol. 2004, 31, 633-642. [CrossRef]

67. Katagiri, Y.; Hozumi, Y.; Kondo, S. Knockdown of Skp2 by siRNA inhibits melanoma cell growth in vitro and in vivo. J. Dermatol. Sci. 2006, 42, 215-224. [CrossRef] 
68. Lin, D.I.; Barbash, O.; Kumar, K.G.; Weber, J.D.; Harper, J.W.; Klein-Szanto, A.J.; Rustgi, A.; Fuchs, S.Y.; Diehl, J.A. Phosphorylationdependent ubiquitination of cyclin D1 by the SCF(FBX4-alphaB crystallin) complex. Mol. Cell 2006, 24, 355-366. [CrossRef] [PubMed]

69. Vaites, L.P.; Lee, E.K.; Lian, Z.; Barbash, O.; Roy, D.; Wasik, M.; Klein-Szanto, A.J.; Rustgi, A.K.; Diehl, J.A. The Fbx4 tumor suppressor regulates cyclin D1 accumulation and prevents neoplastic transformation. Mol. Cell. Biol. 2011, 31, 4513-4523. [CrossRef] [PubMed]

70. Akhoondi, S.; Sun, D.; von der Lehr, N.; Apostolidou, S.; Klotz, K.; Maljukova, A.; Cepeda, D.; Fiegl, H.; Dafou, D.; Marth, C.; et al. FBXW7/hCDC4 is a general tumor suppressor in human cancer. Cancer Res. 2007, 67, 9006-9012. [CrossRef]

71. Rajagopalan, H.; Jallepalli, P.V.; Rago, C.; Velculescu, V.E.; Kinzler, K.W.; Vogelstein, B.; Lengauer, C. Inactivation of hCDC4 can cause chromosomal instability. Nature 2004, 428, 77-81. [CrossRef]

72. Barber, T.D.; McManus, K.; Yuen, K.W.; Reis, M.; Parmigiani, G.; Shen, D.; Barrett, I.; Nouhi, Y.; Spencer, F.; Markowitz, S.; et al. Chromatid cohesion defects may underlie chromosome instability in human colorectal cancers. Proc. Natl. Acad. Sci. USA 2008, 105, 3443-3448. [CrossRef] [PubMed]

73. Fu, J.; Qiu, H.; Cai, M.; Pan, Y.; Cao, Y.; Liu, L.; Yun, J.; Zhang, C.Z. Low cyclin F expression in hepatocellular carcinoma associates with poor differentiation and unfavorable prognosis. Cancer Sci. 2013, 104, 508-515. [CrossRef]

74. Lehman, N.L.; Tibshirani, R.; Hsu, J.Y.; Natkunam, Y.; Harris, B.T.; West, R.B.; Masek, M.A.; Montgomery, K.; van de Rijn, M.; Jackson, P.K. Oncogenic regulators and substrates of the anaphase promoting complex/cyclosome are frequently overexpressed in malignant tumors. Am. J. Pathol. 2007, 170, 1793-1805. [CrossRef] [PubMed]

75. Geigl, J.B.; Obenauf, A.C.; Schwarzbraun, T.; Speicher, M.R. Defining 'chromosomal instability'. Trends Genet. 2008, 24, 64-69. [CrossRef] [PubMed]

76. Holland, A.J.; Cleveland, D.W. Boveri revisited: Chromosomal instability, aneuploidy and tumorigenesis. Nat. Rev. Mol. Cell Biol. 2009, 10, 478-487. [CrossRef] [PubMed]

77. Storchova, Z.; Kuffer, C. The consequences of tetraploidy and aneuploidy. J. Cell Sci. 2008, 121, 3859-3866. [CrossRef]

78. Janiszewska, M. The microcosmos of intratumor heterogeneity: The space-time of cancer evolution. Oncogene 2020, 39, 2031-2039. [CrossRef] [PubMed]

79. Oh, B.Y.; Shin, H.T.; Yun, J.W.; Kim, K.T.; Kim, J.; Bae, J.S.; Cho, Y.B.; Lee, W.Y.; Yun, S.H.; Park, Y.A.; et al. Intratumor heterogeneity inferred from targeted deep sequencing as a prognostic indicator. Sci. Rep. 2019, 9, 4542. [CrossRef] [PubMed]

80. Swanton, C. Intratumor heterogeneity: Evolution through space and time. Cancer Res. 2012, 72, 4875-4882. [CrossRef]

81. Bakhoum, S.F.; Ngo, B.; Laughney, A.M.; Cavallo, J.A.; Murphy, C.J.; Ly, P.; Shah, P.; Sriram, R.K.; Watkins, T.B.K.; Taunk, N.K.; et al. Chromosomal instability drives metastasis through a cytosolic DNA response. Nature 2018, 553, 467-472. [CrossRef] [PubMed]

82. Gao, C.; Su, Y.; Koeman, J.; Haak, E.; Dykema, K.; Essenberg, C.; Hudson, E.; Petillo, D.; Khoo, S.K.; Vande Woude, G.F. Chromosome instability drives phenotypic switching to metastasis. Proc. Natl. Acad. Sci. USA 2016, 113, 14793-14798. [CrossRef] [PubMed]

83. Tijhuis, A.E.; Johnson, S.C.; McClelland, S.E. The emerging links between chromosomal instability (CIN), metastasis, inflammation and tumour immunity. Mol. Cytogenet 2019, 12, 17. [CrossRef] [PubMed]

84. Pailler, E.; Auger, N.; Lindsay, C.R.; Vielh, P.; Islas-Morris-Hernandez, A.; Borget, I.; Ngo-Camus, M.; Planchard, D.; Soria, J.C.; Besse, B.; et al. High level of chromosomal instability in circulating tumor cells of ROS1-rearranged non-small-cell lung cancer. Ann. Oncol. 2015, 26, 1408-1415. [CrossRef]

85. Lee, A.J.; Endesfelder, D.; Rowan, A.J.; Walther, A.; Birkbak, N.J.; Futreal, P.A.; Downward, J.; Szallasi, Z.; Tomlinson, I.P.; Howell, M.; et al. Chromosomal instability confers intrinsic multidrug resistance. Cancer Res. 2011, 71, 1858-1870. [CrossRef]

86. Wang, W.; Zhang, Y.; Chen, R.; Tian, Z.; Zhai, Y.; Janz, S.; Gu, C.; Yang, Y. Chromosomal instability and acquired drug resistance in multiple myeloma. Oncotarget 2017, 8, 78234-78244. [CrossRef]

87. Liu, H.; Xing, Y.; Yang, S.; Tian, D. Remarkable difference of somatic mutation patterns between oncogenes and tumor suppressor genes. Oncol. Rep. 2011, 26, 1539-1546. [CrossRef] [PubMed]

88. Saito, Y.; Koya, J.; Araki, M.; Kogure, Y.; Shingaki, S.; Tabata, M.; McClure, M.B.; Yoshifuji, K.; Matsumoto, S.; Isaka, Y.; et al. Landscape and function of multiple mutations within individual oncogenes. Nature 2020, 582, 95-99. [CrossRef]

89. Finlay, C.A.; Hinds, P.W.; Levine, A.J. The p53 proto-oncogene can act as a suppressor of transformation. Cell 1989, 57, 1083-1093. [CrossRef]

90. Jenkins, J.R.; Rudge, K.; Chumakov, P.; Currie, G.A. The cellular oncogene p53 can be activated by mutagenesis. Nature 1985, 317, 816-818. [CrossRef]

91. Lane, D.P. Cell immortalization and transformation by the p53 gene. Nature 1984, 312, 596-597. [CrossRef]

92. McAndrew, E.N.; McManus, K.J. The enigmatic oncogene and tumor suppressor-like properties of RAD54B: Insights into genome instability and cancer. Genes Chromosomes Cancer 2017, 56, 513-523. [CrossRef]

93. Jeusset, L.M.; McManus, K.J. Ubiquitin Specific Peptidase 22 Regulates Histone H2B Mono-Ubiquitination and Exhibits Both Oncogenic and Tumor Suppressor Roles in Cancer. Cancers 2017, 9, 167. [CrossRef]

94. Kilpinen, S.; Autio, R.; Ojala, K.; Iljin, K.; Bucher, E.; Sara, H.; Pisto, T.; Saarela, M.; Skotheim, R.I.; Bjorkman, M.; et al. Systematic bioinformatic analysis of expression levels of 17,330 human genes across 9783 samples from 175 types of healthy and pathological tissues. Genome Biol. 2008, 9, R139. [CrossRef] 
95. Rhodes, D.R.; Kalyana-Sundaram, S.; Mahavisno, V.; Varambally, R.; Yu, J.; Briggs, B.B.; Barrette, T.R.; Anstet, M.J.; Kincead-Beal, C.; Kulkarni, P.; et al. Oncomine 3.0: Genes, pathways, and networks in a collection of 18,000 cancer gene expression profiles. Neoplasia 2007, 9, 166-180. [CrossRef]

96. Robak, T.; Huang, H.; Jin, J.; Zhu, J.; Liu, T.; Samoilova, O.; Pylypenko, H.; Verhoef, G.; Siritanaratkul, N.; Osmanov, E.; et al. Bortezomib-based therapy for newly diagnosed mantle-cell lymphoma. N. Engl. J. Med. 2015, 372, 944-953. [CrossRef]

97. Swords, R.T.; Erba, H.P.; DeAngelo, D.J.; Bixby, D.L.; Altman, J.K.; Maris, M.; Hua, Z.; Blakemore, S.J.; Faessel, H.; Sedarati, F.; et al. Pevonedistat (MLN4924), a First-in-Class NEDD8-activating enzyme inhibitor, in patients with acute myeloid leukaemia and myelodysplastic syndromes: A phase 1 study. Br. J. Haematol. 2015, 169, 534-543. [CrossRef] [PubMed]

98. Skaar, J.R.; Pagan, J.K.; Pagano, M. SCF ubiquitin ligase-targeted therapies. Nat. Rev. Drug Discov. 2014, 13, 889-903. [CrossRef] [PubMed]

99. Ludwig, H.; Khayat, D.; Giaccone, G.; Facon, T. Proteasome inhibition and its clinical prospects in the treatment of hematologic and solid malignancies. Cancer 2005, 104, 1794-1807. [CrossRef] [PubMed]

100. Schettini, F.; Giudici, F.; Bernocchi, O.; Sirico, M.; Corona, S.P.; Giuliano, M.; Locci, M.; Paris, I.; Scambia, G.; De Placido, S.; et al. Poly (ADP-ribose) polymerase inhibitors in solid tumours: Systematic review and meta-analysis. Eur. J. Cancer 2021, 149, 134-152. [CrossRef]

101. Sajesh, B.V.; Guppy, B.J.; McManus, K.J. Synthetic genetic targeting of genome instability in cancer. Cancers 2013, 5, 739-761. [CrossRef]

102. Burdova, K.; Yang, H.; Faedda, R.; Hume, S.; Chauhan, J.; Ebner, D.; Kessler, B.M.; Vendrell, I.; Drewry, D.H.; Wells, C.I.; et al. E2F1 proteolysis via SCF-cyclin F underlies synthetic lethality between cyclin F loss and Chk1 inhibition. EMBO J. 2019, 38, e101443. [CrossRef]

103. Brough, R.; Gulati, A.; Haider, S.; Kumar, R.; Campbell, J.; Knudsen, E.; Pettitt, S.J.; Ryan, C.J.; Lord, C.J. Identification of highly penetrant Rb-related synthetic lethal interactions in triple negative breast cancer. Oncogene 2018, 37, 5701-5718. [CrossRef]

104. Kroll, E.S.; Hyland, K.M.; Hieter, P.; Li, J.J. Establishing genetic interactions by a synthetic dosage lethality phenotype. Genetics 1996, 143, 95-102. [CrossRef] [PubMed]

105. Narayan, R.S.; Molenaar, P.; Teng, J.; Cornelissen, F.M.G.; Roelofs, I.; Menezes, R.; Dik, R.; Lagerweij, T.; Broersma, Y.; Petersen, N.; et al. A cancer drug atlas enables synergistic targeting of independent drug vulnerabilities. Nat. Commun. 2020, 11, 2935. [CrossRef] [PubMed]

106. Bungsy, M.; Palmer, M.C.L.; Jeusset, L.M.; Neudorf, N.M.; Lichtensztejn, Z.; Nachtigal, M.W.; McManus, K.J. Reduced RBX1 expression induces chromosome instability and promotes cellular transformation in high-grade serous ovarian cancer precursor cells. Cancer Lett. 2021, 500, 194-207. [CrossRef] [PubMed]

107. Cecchini, C.; Pannilunghi, S.; Tardy, S.; Scapozza, L. From Conception to Development: Investigating PROTACs Features for Improved Cell Permeability and Successful Protein Degradation. Front. Chem 2021, 9, 672267. [CrossRef]

108. Hughes, G.R.; Dudey, A.P.; Hemmings, A.M.; Chantry, A. Frontiers in PROTACs. Drug Discov. Today 2021. [CrossRef] [PubMed]

109. Sakamoto, K.M.; Kim, K.B.; Kumagai, A.; Mercurio, F.; Crews, C.M.; Deshaies, R.J. Protacs: Chimeric molecules that target proteins to the Skp1-Cullin-F box complex for ubiquitination and degradation. Proc. Natl. Acad. Sci. USA 2001, 98, 8554-8559. [CrossRef]

110. Burslem, G.M.; Crews, C.M. Proteolysis-Targeting Chimeras as Therapeutics and Tools for Biological Discovery. Cell 2020, 181, 102-114. [CrossRef]

111. Huang, X.; Liu, Y.; Wang, Y.; Bailey, C.; Zheng, P.; Liu, Y. Dual Targeting Oncoproteins MYC and HIF1alpha Regresses Tumor Growth of Lung Cancer and Lymphoma. Cancers 2021, 13, 694. [CrossRef] [PubMed]

112. Wu, S.; Jiang, Y.; Hong, Y.; Chu, X.; Zhang, Z.; Tao, Y.; Fan, Z.; Bai, Z.; Li, X.; Chen, Y.; et al. BRD4 PROTAC degrader ARV-825 inhibits T-cell acute lymphoblastic leukemia by targeting 'Undruggable' Myc-pathway genes. Cancer Cell Int. 2021, 21, 230. [CrossRef] [PubMed]

113. Lu, J.; Qian, Y.; Altieri, M.; Dong, H.; Wang, J.; Raina, K.; Hines, J.; Winkler, J.D.; Crew, A.P.; Coleman, K.; et al. Hijacking the E3 Ubiquitin Ligase Cereblon to Efficiently Target BRD4. Chem. Biol. 2015, 22, 755-763. [CrossRef] [PubMed]

114. Sun, B.; Fiskus, W.; Qian, Y.; Rajapakshe, K.; Raina, K.; Coleman, K.G.; Crew, A.P.; Shen, A.; Saenz, D.T.; Mill, C.P.; et al. BET protein proteolysis targeting chimera (PROTAC) exerts potent lethal activity against mantle cell lymphoma cells. Leukemia 2018, 32, 343-352. [CrossRef]

115. Zhang, X.; Lee, H.C.; Shirazi, F.; Baladandayuthapani, V.; Lin, H.; Kuiatse, I.; Wang, H.; Jones, R.J.; Berkova, Z.; Singh, R.K.; et al. Protein targeting chimeric molecules specific for bromodomain and extra-terminal motif family proteins are active against pre-clinical models of multiple myeloma. Leukemia 2018, 32, 2224-2239. [CrossRef] [PubMed] 